\title{
42. Türk yazılı basınında COVID-19 terimleri: Sorunlar ve çözüm önerileri
}

Ayşe TURAN 1

Ceylan YILDIRIM ${ }^{2}$

APA: Turan, A.; Yıldırım, C. (2021). Türk yazılı basınında COVID-19 terimleri: Sorunlar ve çözüm önerileri. RumeliDE Dil ve Edebiyat Araştırmaları Dergisi, (0̈9), 525-551. DOI: 10.29000/rumelide.983918.

$\ddot{0} \mathbf{z}$

Bu çalışmada, Türk yazılı basınında COVID-19 terimlerinin kullanımına ilişkin sorunların açığa çıkarılması ve sorunların çözümü için öneri sunulması amaçlanmaktadır. Bu çerçevede, COVID-19 terimleri, Türk yazılı basınında yer alan COVID-19 haberleri aracılığıyla incelenmektedir. COVID-19 terimlerinin kullanımında, Türkiye'deki terminolojik düzenlemelerin ardından herhangi bir değişiklik olup olmadığını görebilmek için terimlerin kullanımı, hastalığın ilk çıktığı dönem ile terminolojik düzenlemelerden sonraki dönem olmak üzere iki dönemde incelenmektedir. Ayrıca, terimlerin uygunluğu önceden belirlenen terim değerlendirme ölçütlerine göre değerlendirilmektedir. Bu doğrultuda, çalışmada, ilk olarak, basında kullanılan COVID-19 terimlerinin değerlendirilmesinde başvurulacak ölçütler belirlenmekte, ardından, COVID-19 terim sorunlarına ilişkin söylemler Türkiye bağlamında ele alınmakta ve sorunların çözümü için hangi terminolojik düzenlemelerin gerçekleştirildiği açığa çıkarılmaktadır. Daha sonra, Türk yazılı basınından haber örnekleriyle, COVID19 terimlerinin, terminolojik düzenlemeler öncesi dönem ile sonrası dönem olmak üzere iki dönemdeki kullanımlarının analizi gerçekleştirilmektedir. Çalışmada elde edilen veriler ışığında, COVID-19 ile ilgili Türkiye'deki terminolojik düzenlemeler öncesi dönem haberlerinde, daha ziyade yabancı kökenli terimlerin kullanıldığı ve ödünçlenen yabancı kökenli terimlerin Türkçe yazılışlarında farklılıklar olduğu gözlemlenmiştir. Aynı haber metni içerisinde dahi aynı kavramın farklı belirtimlerle karşılandığı görülmüştür. Yabancı kökenli terim kullanımının, basın dilinde hedef kitle olan halka hitap etmediği ve açıklık ilkesiyle örtüşmediği anlaşılmıştır. Terminolojik düzenlemeler sonrası dönem haberlerinde ise yabancı kökenli terim kullanımının kısmen devam ettiği fakat terimlerin Türkçe karşılıklarının kullanımının yaygınlaştığını söylemek mümkündür. Bununla birlikte, hayati öneme sahip alanlarda teknik terim kurullarının hazır bulundurulması gerek Türkçe karşılıkların daha kısa sürede önerilmesiyle terim sorunlarının çözülmesine gerek dilin gelişimine katkı sağlayacaktır.

Anahtar kelimeler: Türk yazılı basını, COVID-19, terim sorunları, belirtim değerlendirme ölçütleri, terminolojik düzenlemeler, Türkçe terim karşıllkları

\section{COVID-19 Terms in Turkish print media: problems and solution suggestions}

\begin{abstract}
This study aims to reveal the problems related to the use of COVID-19 terms in the Turkish print media and to offer suggestions for solving the current problems. In this context, COVID-19 terms are examined through COVID-19 news in the Turkish print media. In order to see whether there is any change in the
\end{abstract}

YL, Hacettepe Üniversitesi, Sosyal Bilimler Enstitüsü, Mütercim Tercümanlı ABD (Ankara, Türkiye) ayseturan87@gmail.com, ORCID ID: 0000-0001-8691-4767 [Araştırma makalesi, Makale kayıt tarihi: 10.07.2021-kabul tarihi: 20.08.2021; DOI: $10.29000 /$ rumelide.983918]

Dr. Öğr. Üyesi, Hacettepe Üniversitesi, Edebiyat Fakültesi, Fransızca Mütercim Tercümanlık ABD (Ankara, Türkiye), ceylany@hacettepe.edu.tr, ORCID ID: 0000-0001-8456-0299

Adres | Address

RumeliDE Dil ve Edebiyat Araştırmalar Dergisi $\quad$ RumeliDE Journal of Language and Literature Studies Osmanağa Mahallesi, Mürver Çiçeği Sokak, No:14/8 $\quad$ Osmanağa Mahallesi, Mürver Çiçeği Sokak, No:14/8

Kadıköy - İSTANBUL / TÜRKIYE 34714 Kadıköy - ISTANBUL / TURKEY 34714

e-posta: editor@rumelide.com e-mail: editor@rumelide.com, tel: +90 505 7958124, +90 2167730616 phone: +90 505 7958124, +90 2167730616 
use of COVID-19 terms after the terminological regulations in Turkey, the use of the terms is examined in two periods, first the period before the terminological regulations and then the period after the terminological regulations. In addition, the appropriateness of the terms is evaluated according to the term evaluation criteria determined beforehand. In this regard, firstly, the criteria to be used in the evaluation of COVID-19 terms used in the press are determined, then the discourses on COVID-19 term problems are discussed in the context of Turkey and the terminological attempts and regulations in Turkey related to COVID-19 are revealed. Then, by using news samples from the Turkish print media, the use of COVID-19 terms in two periods, the period before and after the terminological regulations, is analyzed. In this study, it has been observed that in the news before the terminological regulations in Turkey regarding COVID-19, foreign origin terms are used and there are differences in the Turkish spelling of the foreign origin terms. It has been seen that the same concept is met with different spellings even within the same news text. It has been understood that the use of foreign terms in the language of the press does not address the target audience and does not coincide with the principle of clarity. In the news after terminological regulations, it is possible to say that the use of terms borrowed by foreign origins partially continued, but the use of Turkish equivalents of the terms was published. Finally, having technical term boards ready in vital areas will contribute to solving term problems by offering Turkish equivalents in a shorter time and to the development of the language.

Keywords: Turkish print media, COVID-19, term problems, term evaluation criteria, terminological regulations, Turkish term equivalents

\section{Giriş}

COVID-19'un 11 Mart 2020 tarihinde Dünya Sağlık Örgütü tarafından pandemi ilan edilmesinden bu yana (1 yılı aşkın bir süredir), hayatımızda önemli değişikliklerin meydana geldiğini söylemek mümkündür. $\mathrm{Bu}$ değişikliklerin en temel olarak sosyal yaşamda, iş yaşamında ve politik yaşamda hissedilir olduğu söylenebilir. Ayrıca, sağlık, ekonomi ve eğitim alanlarında da bazı değişim ve dönüşümler gerçekleşmiştir. COVID-19 nedeniyle, sadece eğitim alanında bir anda ön plana çıkan ve eğitimin sürdürülmesinde kilit nokta görevi gören uzaktan eğitim modelini göz önünde bulundursak, özellikle bazı alanlarda köklü değişikliklere neden olan bu salgının, hayatı ne denli etkilediğini anlayabiliriz. Diğer birçok alanda da salgının neden olduğu sorunlara çözüm aranırken, bazı değişikliklerin meydana geldiği söylenebilir fakat bu değişikliklerdeki en temel ortak paydanın, genel olarak, işleri, süreçleri, görevleri ve günlük yaşamdaki birçok etkinliği uzaktan gerçekleştirmek olduğunu söyleyebiliriz. Örnekler arasında, dans, spor, müzik gibi çeşitli hobi ve etkinliklerin, banka işlemleri, fatura ödeme vb. işlemlerin uzaktan gerçekleştirilmesi sayılabilir. İnsan yaşamını direkt olarak konu alan sağlık gibi alanlarda ise işlemleri uzaktan gerçekleștirmenin elbette bir sınırı olmuştur ki bu olağan bir durumdur. Bununla birlikte, sağlık alanında dahi uzaktan takip sistemlerinin kurularak hasta takiplerinin çeşitli şekillerde yapıldığını görebilmekteyiz.

Salgının başlangıcından bu yana, COVID-19 ile ilgili çok sayıda yayın yapıldığını ve gerek yazılı (daha ziyade basında) gerekse sözlü dilde çeşitli söylemlerin oluştuğunu söylemek mümkündür. Salgın sürecinin kendisinin, meydana getirdiği değişikliklerin ve salgına değin daha birçok konunun ele alınması, sürecin daha iyi anlaşılması, sorunların açı̆̆a çıkarılması ve bazı çözüm önerilerinin geliştirilmesi açısından önem arz etmektedir. COVID-19 salgınına ilişkin diğer önemli bir konu da terminolojidir. COVID-19 ile birlikte bu hastalığa ilişkin bir terminoloji gelişmiş ve çeşitli terminolojik sorunlara bağlı bazı söylemler ortaya çıkmıştır. Türkiye bağlamında ele alındığında, bu söylemler arasında, terimlerin tıp literatüründeki kullanımlarının (ör. enfekte, entübe) basında yaygınlaşması ve kurumsal düzeyde en hızlı şekilde Türkçe

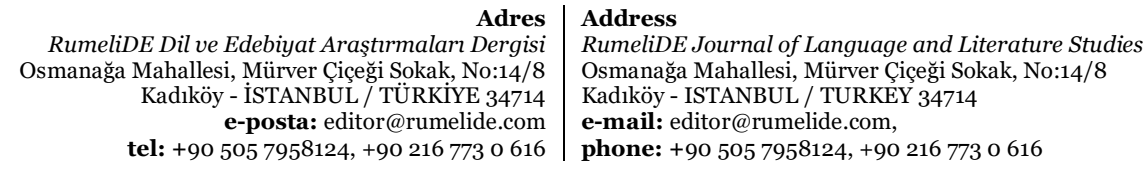


karşılıklarının önerilememesi sebebiyle ortaya çıkan tam anlaşılamama sorunu ve buna bağlı olarak, hastalığın seyrinin olumsuz yönde etkilenebilmesi hususu sayılabilir.

Basına da yansıyan COVID-19 terminolojisine ilişkin sorunlara çözüm olarak, Türkiye'de ulusal düzeyde (T.C. Sağlık Bakanlığı, Cumhurbaşkanlığı Kültür ve Sanat Politikaları Kurulu vb. kurum/kuruluşlarda) bazı girişimlerin olduğu gözlemlenmektedir. Bununla birlikte, tıp terimlerinin basında yabancı kökenleriyle yer alması, halkın büyük çoğunluğunun bazı kavramlara yabancı kalmasıyla ve neticede anlaşılmazlık sorunuyla sonuçlanabilmektedir. Oysaki salgın gibi dünyayı ilgilendiren ve etkileyen sağlı sorunlarının yok olabilmesi için basın dilinin halkın anlayacağı şekilde olması önemlidir. Basın dili geniş kitlelere hitap etmekte ve bilgilendirici olma özelliğiyle, olayların gidişatını ve sonuçlarını önemli ölçüde etkileyebilmektedir. Bu nedenle, basında, yabancı terimlerin ya Türkçe karşlıklarıyla kullanılması ya da böyle bir imkân olmaması durumunda kısa açıklanmalarının yapılması önemlidir. Peki, COVID-19 terimlerinin Türk yazılı basınındaki kullanımı nasıl olmuştur?

Bu çalışmada, COVID-19 terimlerinin yazılı basın organlarından olan gazetelerdeki kullanımı Türkiye bağlamında incelenmekte ve terimlerin kullanımıyla ilgili bazı söylemler ele alınmaktadır. Bu doğrultuda, betimleyici bir yaklaşımıyla, COVID-19 terimlerinin gazete haber metinlerinde nasıl kullanıldıkları açığa çıkarılacak ve terimler belirli belirtim oluşturma ölçütlerine göre değerlendirilecektir. Çalışmada, şu sorulara yanıt aranacaktır: Hastalığın başından bu yana, COVID-19 terimleri, Türkiye'deki gazete haberlerinde ödünçlenerek (yabancı kökenleriyle) mi kullanılmıştır? Bununla birlikte, Türkiye'de ulusal düzeyde gerçekleştirilen bazı terminolojik girişim ve düzenlemelerden sonra, terimlerin kullanımında bir değiş̧iklik olmuş mudur? Türkiye'de COVID-19 terminolojisine ilişsin hangi girişim ve düzenlemeler olmuştur? Bu girişim ve düzenlemeler, COVID-19 terimlerinin basındaki kullanımını nasıl etkilemiştir? COVID-19 terimlerinin gazete haberlerindeki kullanımlarını kısmen gösterebilmek için Türkiye'de yüksek tirajlı gazeteler arasında yer alan Hürriyet, Sabah, Sözcü, Posta, Milliyet gazetelerinin COVID-19 ile ilgili haberleri taranacaktır. 2020 yılındaki bir habere göre, Türkiye'de en çok satan 10 gazete arasında, tirajlarına göre sırasıyla şu gazeteler yer almaktadır: Hürriyet (195309), Sabah (193986), Sözcü (186436), Posta (124634), Milliyet (123565), Yeni Şafak (102516), Akşam (100286), Takvim (87087), Akit (56229), Korkusuz (55981) https://journo.com.tr/tirajlar-2020, Erişim tarihi: 19.05.2021). Türkiye'de COVID-19 terminolojisiyle ilgili düzenlemelerden önce yayımlanan gazete haberleri ile terminolojik düzenlemeler sonrası dönemde yayımlanan gazete haber örneklerinin incelenmesiyle, COVID-19 terimlerinin terminolojik düzenlemeler öncesi ve sonrası dönemlerdeki kullanımlarıyla ilgili farklılıklar açığa çıkarılacak ve terminolojik düzenlemelerden sonra terimlerin kullanımında herhangi bir değişiklik olup olmadığı ortaya koyulacaktır.

Çalışmanın birinci bölümünde, belirtim değerlendirme ölçütleri çalışmamızla ilişkilendirilerek açıklanacaktır. İkinci bölümde, COVID-19 terminolojisi sorunlarına ilişkin bazı söylemler açığa çıkarılacaktır. Üçüncü bölümde, Türkiye'de COVID-19 terminolojisine ilişkin devlet bünyesinde gerçekleştirilen girişim veya düzenlemeler aktarılacaktır. Dördüncü bölümde ise gazete haber örneklerinde yer alan COVID-19 terimleri, Türkiye'deki terminolojik düzenlemeler öncesi ve sonrası dönemdeki kullanımlarına göre karşılaştırmalı olarak incelenecektir. Son olarak, terimlerin "dilsel-mantıksal doğruluk", "açıklık" ve "hedef gruba uygunluk" ölçütlerine uygunluklarının basındaki önemine vurgu yapılarak, terimlerin basındaki kullanımına ilişkin öneride bulunulacaktır.

\section{Belirtim değerlendirme ölçütleri}

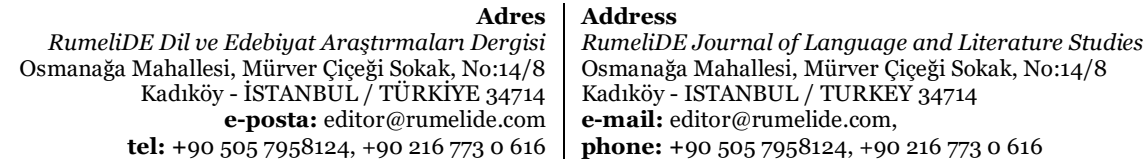

RumeliDE Dil ve Edebiyat Araşttrmaları Dergis tel: +90 $5057958124,+902167730616$ 
Özel alanlardaki iletişimin kalitesi, ilgili özel alandaki terminolojinin kalitesine bağlıdır. Terimler ve tanımları kurallara ve standartlara uygun bir șekilde olușturulursa ilgili özel alanın terminolojisi sağlam temellere dayanır. Bağlam cümleler ile gerekli ek açıklamaların kurallara uygun oluşturulması da terminolojilerin niteliğini artırır. Nitelikli terminolojiler ise iletişim kaynaklı sorunları en aza indirir.

Bununla birlikte, terminolojik sorunların çözümü için bazı değerlendirme ölçütleri, kural ve ilkelerin bilinmesi önemlidir. Sık karşılaşılan sorunlardan biri de tek bir kavram için çok sayıda belirtimin olmasıdır. Bu noktada, uygun belirtimin seçimi için belirli ölçütlere göre değerlendirme yapmak önemlidir:

"Bir kavram için birden çok belirtimin kullanılması sık rastlanan olaylardandır. Bu durum metinlerin anlaşılabilirliğini ve özellikle hukuksal güvencesini etkiler. Bu nedenle bütün belirtimlerin değerlendirilmesi, hangi belirtimin tercih edileceği konusunda daha sonra verilecek kararlara temel oluşturacaktır" (Drewer, Pulitano, Schmitz 2015: 93)

Terminolojinin amacı ve işlevi doğrultusunda, hangi belirtim değerlendirme ölçütlerinin ön planda tutulacağı değişebilir. Bu doğrultuda, tüm belirtim değerlendirme ölçütlerinin hepsine aynı anda uygunluk gösterilemeyebilir. Belirtim değerlendirme ölçütleri arasında aşağıdaki ölçütler sayılabilir:

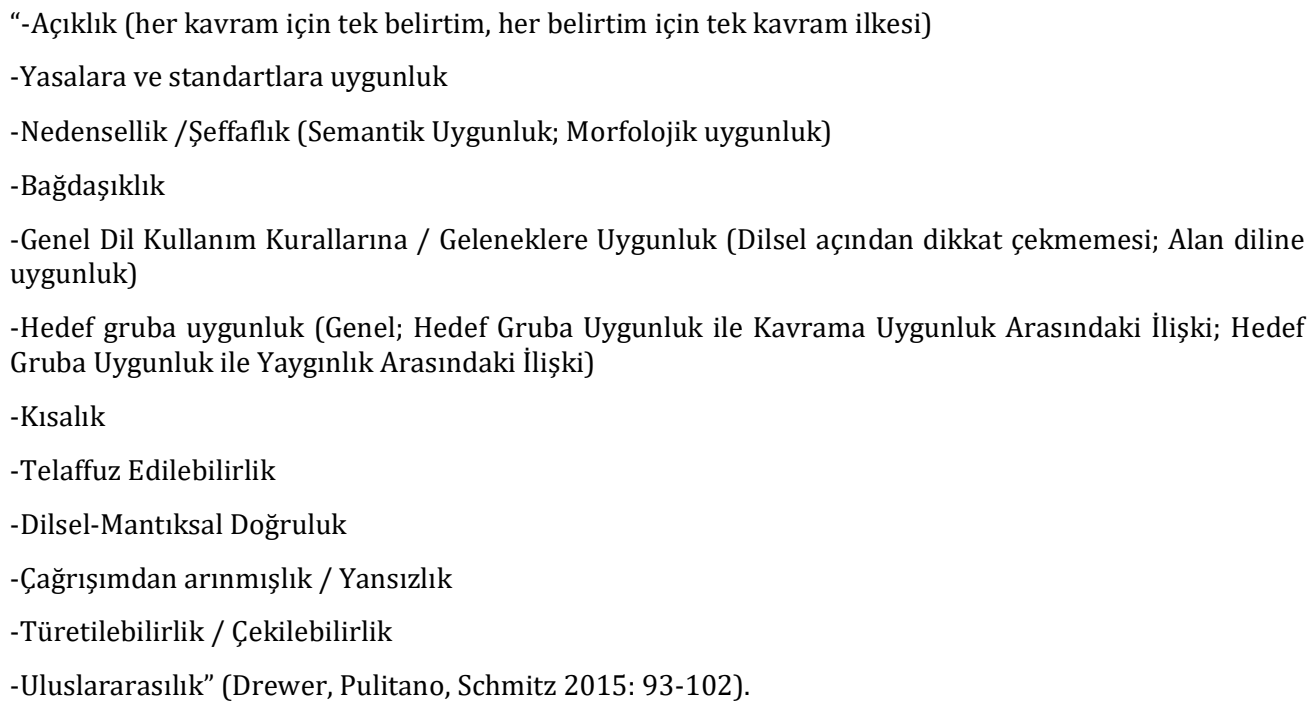

Basında kullanılan COVID-19 terimleriyle ilgili olarak, yukarıda belirtilen belirtim değerlendirme ölçütlerinden "Hedef gruba uygunluk", "Açıklık", "Dilsel-Mantıksal Doğruluk" ile "Türetilebilirlik / Çekilebilirlik" ölçütlerine uygunluğun öncelikli öneme sahip olduğu düşünülmektedir. Bu nedenle, çalışmamızın dördüncü bölümünde, gazete haberlerinde yer alan COVID-19 terimlerinin değerlendirmesinde bu ölçütlere uygunluk -"Hedef gruba uygunluk", "Açıklık", "Dilsel-Mantıksal Doğruluk" ve "Türetilebilirlik / Çekilebilirlik"- temel alınacaktır. Öyle ki salgın söz konusu olduğunda, basında geçen hastalıkla ilgili terimlerin açık ve anlaşılır olması, hedef kitlece anlaşılır olması, dilsel/mantıksal açıdan doğru olması, hastalı̆̆ın gelişimiyle ortaya çıkan yeni terimlere paralel türetilebilir/çekilebilir olması önemlidir. Zira basın dili geniş kitlelere, genel olarak halka hitap etmekte ve salgının olumlu seyri için hastalıkla ilgili bilgilerin halk tarafından anlaşılması önem arz etmektedir. Basında yabancı kökenli tıp terimlerinin kullanılması terimlerin halk tarafından anlaşılamaması sorununu beraberinde getirebilmektedir. Özellikle COVID-19 ile birlikte ilk kez duyulan yabancı kökenli terimlerin halk tarafından anlaşılmasını beklemek üzerinde düşünülmesi gereken bir konudur.

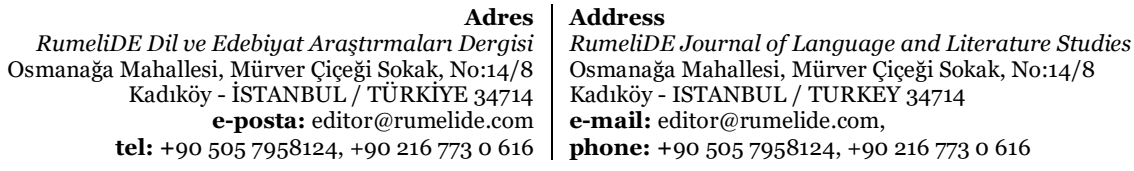


Belirtimlerin değerlendirme ölçütlerine uygunluklarının yanı sıra terimlerin uygun bir şekilde tanımlanması da önemlidir. COVID-19 terimlerini kurallara uygun olarak tanımlamak veya mevcut tanımları kurallara uygunlukları açısından değerlendirerek gerekli düzenleme ve güncellemeleri yapmak büyük avantajları beraberinde getirecektir. En önemlisi de terimler doğru anlaşılacak ve doğru işlem ve uygulamalarla süreç olumlu yönde etkilenecektir. İyi bir tanım için aşağıdaki tanım yazma kurallarına dikkat edilebilir:

“- İyi bir tanım kısadır (ansiklopedi maddesi gibi değildir).

- Amacı ve hedef grubu dikkate alır.

- İdeal durumda, tanımlanan kavramın temel özelliklerini içerir (içeriksel tanım).

- Belirtimi eş anlamlı yardımıyla açıklamaz.

- Tanımlar totolojik olmamalıdır, yani aynı şey farklı sözcüklerle anlatılmamalıdır (personel görüşmesi = personelle yapılan görüşme).

- $\quad$ Kısır döngüye sahip olmamalıdır (parlak = mat olmayan; mat = parlak olmayan).

- Tanımlarda cümle yapısı olumsuz olmaz (XYZ, ABC değildir)” (Drewer, Pulitano, Schmitz 2015: 63).

Terminolojinin öneminin, tüm dünya için bir tehdit haline gelen COVID-19 ile birlikte, daha görünür hale geldiğini söylemek mümkündür. COVID-19 ile ilgili terimlerin yabancı kökenli kullanımlarına bağlı anlaşılamamaları ve Türkçe karşılıkları olan veya Türkçe karşılığı önerilmiş terimlerin yabancı kökenli kullanımlarının devam etmesi Türkiye'deki COVID-19 terim sorunlarıyla ilgili söylemler arasında sayılabilir. Terminolojik sorunların hastalığın seyrinde etkili olduğunu ve hatta gidișatı olumsuz yönde etkileyebileceğini söylemek mümkündür. Zülfikar, "Gündemi Meşgul Eden Sağlık Terimleri” (2020) başlıklı yazısında, COVID-19 ile gündeme gelen sağlık terimlerinin batı kökenli kullanımları nedeniyle tam anlaşılamadıklarını ve buna bağlı olarak gerekli bilginin edinilemediğini vurgulamaktadır:

\begin{abstract}
"Gazetelerde haberler, uzmanların ifadelerine bağlı olarak benzer terimlerle yazılıyor. Çok kimse, bu hassas dönemde insan sağlığıyla doğrudan ilgili olan bu kelimelerin ne demek olduğunu bilmiyor; bunlara şüpheyle bakıyor, bunlardan ürküyor. Dinleyicilerin dikkat kesildiği haber programlarında uzmanların, bilim adamlarının sözlerinde geçen bu kelimelerden dolayı yeterince bilgi edinilemiyor. Sağlık çalışanları, haberciler, yorumcular, bu terimleri kullanırken örnek olarak bunlardan semptom yerine -bir defa olsun- karşılığı olan belirti kelimesini kullanıp bu terime bir açıklık getirmiyor" (Zülfikar 2020: 10).
\end{abstract}

Yanı sıra, Özdoğan, sağlık terimlerinin anlaşılmasının ve aralarındaki farkın (epidemi -pandemi vb.) bilinmesinin büyük öneme sahip olduğunu şu sözlerle vurgulamaktadır: "Özellikle bir halk sağlığı tehdidi ile ilgili olduklarında, bu tür terimleri öğrenmek ve anlamak gerçekten önemlidir. Sonuçta, "sosyal mesafenin" gerçekten ne anlama geldiğini bile bilmiyorsanız, bunu nasıl yapmanız beklenebilir? (Özdoğan 2020). COVID-19 ile ilgili terminolojik sorunlar karşısında, Türkiye'de bazı terminolojik girişim ve düzenlemeler olmuştur. COVID-19 ile ilgili Türkiye'deki bazı terminolojik girişim ve düzenlemeleri ele almadan önce, terminolojik sorunlara ilişkin bazı söylemler aktarılacaktır.

\title{
2. Türkiye'deki COVID-19 terminolojisi sorunlarıyla ilgili söylemler
}

Konuyla ilgili basılı ve elektronik kaynaklar üzerinden yaptığımız tarama neticesinde, COVID-19 terminolojisi sorunlarıyla ilgili bazı söylemlere ulaşılmıştır. Zülfikar, yabancı sözcük kullanımının hastalıkla (COVID-19) ilgili bilgilerin anlaşılmaması sorununu beraberinde getirdiğine şu sözlerle vurgu yapmaktadır: “... İnsanları çaresiz bırakan bir hastalığın yabancı kelimelerle anlatılması karşısında bigâne (yabancı)

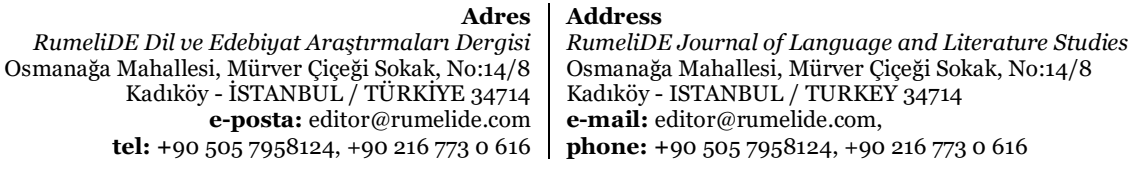


kalınması da kabul edilecek bir durum değildir. Keşke hepsi Türkçeye kazandırılmış, açık, berrak bir terim olan yoğun bakım gibi olsaydı." (2020: 11)

Ayrıca, Zülfikar'ın şu sözleri, anlaşılmayan yabancı terimlerin halk tarafından çözümlenmeye ve anlamlandırılmaya çalışıldığına işaret etmektedir: "Yazılı ve sözlü yayınlarla halka daha pek çok Batı kökenli başka kelimeler de dayatıldı. Halk onlara kendince anlamlar yakıştırdı” (2020: 13). Oysaki çeşitli özel alanlarda terim kurullarının devlet bünyesinde hazır bulundurulması ve özellikle sağlık gibi hassas alanlarda hemen harekete geçilmesi, terimlerin uzmanlarca en uygun karşıllklarının önerilmesini ve kullanılmasını sağlayabilir. Bu durum şüphesiz hastalığın seyrine de olumlu yansıyacaktır.

Altun, COVID-19'un ortaya çıkışından yaklaşık üç ay sonra, 28 Mart 2020 tarihli Facebook Dil Bilimi Linguistics grubundaki paylaşımında, terminolojiyle ilgili sorunları "Salgın Günlerinde Sözcükler" başlı̆̆ı altında şu sözlerle ifade etmiștir:

"Çokça duyuyoruz bu sözcükleri: pandemi, bulaş, entübe, test, pozitif, negatif, karantina, izolasyon, enfeksiyon, epidemi...Bir de Korona ve Corona arasında gidip gelişler var. TRT Koronavirüs alt yazısı geçerken NTV Coronavirüs yazıyor... Ve daha da fazlasını doktorların ağzından duyuyoruz. Latince ve Yunanca kökenli terimler kullanarak bize durumu özetliyorlar...Biz dilciler bu işin neresindeyiz!.. İzleyici mi kalacağız yoksa ön alacak mıyız?"

(https://www.facebook.com/groups/50794706990/posts/10156566941991991, Erişim Tarihi: 16.05.2021).

Altun'un yukarıdaki aktarımıyla, yabancı kökenli terim kullanımı ile belirtimlerin farklı yazılışlarından kaynaklı sıkıntıya vurgu yaptığını ve dil uzmanlarına çözüm için çağrıda bulunduğunu söylemek mümkündür.

Altun, 17 Nisan 2021 tarihli paylaşımında ise COVID-19 terimlerinin yazılışlarıyla ilgili bir standardın sağlanamadığına vurgu yaparak bu terimlerden bazılarını aşağıdaki şekilde sıralamıştır:

“Birbirinden farklı sözcükler, aynı sözcüklerin farklı yazılışları...Bir standart tutturulamamış görünüyor:

Corona salgını

Covid-19 pandemisi

Covid-19 salgını

Covid önlemleri

Korona virüsü salgını

Koronavirüs

Kovid-19 salgını

Küresel pandemi

Mutant virüs

Mutasyonlu corona..."

(https://www.facebook.com/groups/50794706990/posts/10157463438721991, Erişim tarihi: 16.05.2021)

Altun'un yukarıdaki paylaşımı, hastalığın ortaya çıkışının üzerinden bir yıldan fazla bir süre geçmesine rağmen, COVID-19 terminolojisiyle sorunların hala devam ettiğine işaret etmektedir.

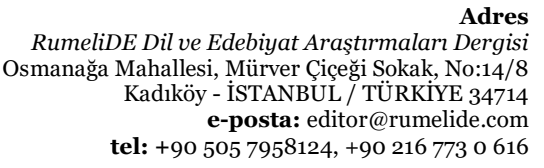

Adres

(4)

RumeliDE Journal of Language and Literature Studies

Osmanağa Mahallesi, Mürver Çiçeği Sokak, No:14/8

Kadıköy - ISTANBUL / TURKEY 34714

e-mail: editor@rumelide.com,

phone: +90 $5057958124,+902167730616$ 
Eker'in 3 Nisan 2020 tarihli aşağıdaki paylaşımı ise, hastalığın gelişimiyle birlikte Türkçe karşılıkları bulunan bazı yeni yabancı terimlerin Türkçe karşılıklarının gözden geçirilmesi ve bu konuda uzman görüşüne başvurulması gerekliliğine işaret etmektedir:

"Her ayni görünen ayni değildir II"

Taç virüs (koronavirüs) ve sosyal mesafe: bir yanlişin kenarindan dönmek

Bir iki gün önce bir haber-yorum kanallarının birinde söz arasında "sosyal mesafe" terimi gündeme gelince sosyoloji profesörü olan yorumcu "sosyal mesafe" yanlış, doğrusu "fiziksel mesafe" olmalı dedi...

Bir de "distance" yerine "distancing" kullanılıyor, bunu da yeni fark ettim. Birine MESAFE diğerine MESAFELEME mi demek lazım?...

Tabii bizdeki bu hatanın kaynağı Batı'nın popüler haber kanalları ve hassiyet ve dikkat ayarı düşük Türkçeye aktarıcılar.

İngilizcede "Social distancing veya Physical distancing olarak ifade edilen kavramı Türkçede Fiziksel mesafeleme veya Sosyal mesafeleme olarak mı adlandırmak gerekiyor?

En iyisi uzmanından bir toplumbilimciden en doğru görüşü almak."

(https://www.facebook.com/SERA1962/posts/2515528488685921, Erişim tarihi: 16.05.2021)

Yılmaz yabancı terimlerin Türkçelerinin kullanılması gerekliliğini şu sözlerle ifade etmektedir:

“...Korona salgınına bağlı olarak iletişim araçlarında ve sosyal medya mecralarında Türkçeleri olduğu hâlde sıklıkla yabancı kelime kullanılmaya başlanmıştı. Türkçe sevdalısı olan bizler, sosyal medya ortamında bu gidişatın doğru olmadığını dile getirmeye çalışıyorduk. Bu hususta Twitter ortamında "bulaş" kullanımının yanlış olduğunu yazmıştım. Son olarak şu tweeti atmıştım: Türkçenin sevdalıları olan bizlerin sabrı, öfkesi "doruğa ulaşma"dan șu "pik"iniz, Türkçenin "doruk"uyla tanıșsın; güzelim Türkçemize lütfen "bulaş”masın!...

(https://www.facebook.com/groups/50794706990/posts/10156638737476991, Erişim tarihi: 16.05.2021)

Yılmaz’ın yukarıdaki aktarımı, çeşitli medya organlarında terimlerin yabancı kökenli kullanımlarının doğru bir gidişat olmadığını ve hastalığın Türkçe anlatılmasının önemini vurgulamaktadır.

Yukarıdaki bilgiler ıșığında, COVID-19 terminolojisiyle ilgili Türkiye'deki bazı söylemlerin, terimlerin yabancı kökenli kullanımlarına bağlı gelişen anlaşılmama sorunu ve yabancı terimlerin dilimizde çeşitli yazılış biçimleriyle yer alması sorunu üzerine şekillendiğini söylemek mümkündür. Zülfikar (2020), uzmanların ve habercilerin batı kökenli sağllk terimlerini kullanmalarının anlaşılmama sorununa neden olabileceğine vurgu yapmıștır. Öyle ki, özellikle geniş kitlelere hitap eden gazete ve televizyon haberlerinde COVID-19 terimlerinin Türkçe karşılıklarının kullanılmaması çok önemli bilgilerin anlaşılmamasına neden olmaktadır. Bir tıp uzmanı meslektaşlarına hitap ederken veya bilimsel çalışmalarında uluslararasılık ilkesine uygun olarak batı kökenli terimleri kullanabilir fakat bir haber kanalında konuşuyorsa veya haber yazısı yazıyorsa terimleri herkesin anlayabileceği şekilde aktarması önemlidir. Bu doğrultuda, Türkçe yazarken Sağlık Bakanlığı'nın kılavuzunu kullanmak ve ayrıca Türkiye'deki resmi kurum ve kuruluşlarca yabancı terimler için önerilen Türkçe karşılıkları kullanmak, hem hastalıkla ilgili iletişimin doğru ve güçlü hale gelmesine hem de Türkçe'nin doğru ve uygun kullanımına olanak sağlayacaktır. Bir hekim veya bilim insanı yabancı dilde konuşup yazarken elbette Dünya Sağlık Örgütü'nü referans alabilir fakat Türkçe düşünebilmek ve düşündürebilmek için Türkçe konuşmak ve yazmak esastır.

Yapılan terminolojik çalışma veya düzenlemelerin COVID-19 salgınının gidişatında önemli bir etkiye sahip olduğu söylenebilir çünkü sağlık alanında terimlerin anlaşılması, daha da önemlisi doğru anlaşılması insan

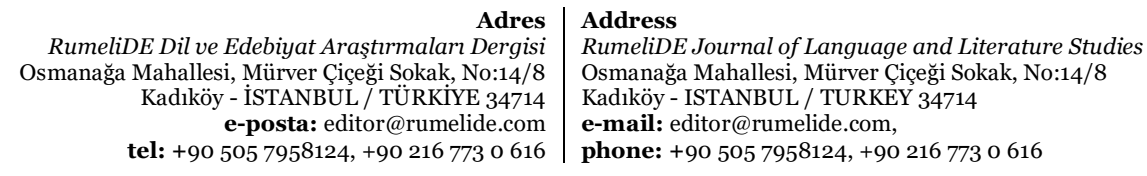


yaşamında önemli bir yere sahiptir. Bir sonraki bölümde, Türkiye'de COVID-19 terminolojisi ile ilgili olarak yapılan bazı çalıșma veya düzenlemeler ele alınacaktır.

\title{
3.Türkiye'de COVID-19 terminolojisi çalışmaları ve ilgili bazı düzenlemeler
}

COVID-19 terminolojisi ile ilgili olarak, Türkiye'de bazı bireysel ve kurumsal girişimlerin olduğunu söylemek mümkündür. Bunlardan biri, Üren'in, 9 Nisan 2020 tarihli A'dan Z'ye Kovid-19: Koronavirüs terimleri sözlüğü başlıklı yazısıdır. Üren bu yazısında, "Koronavirüs salgınıyla birlikte hayatımıza giren sağlı terimlerini biyoloji, tedavi ve önlemler başlıkları altında açıla"maktadır (https://www.indyturk.com/node/160731, Erişim tarihi: 14.05.2021). Haberin tarihi, Üren'in yazısını, koronavirüsün salgın olarak kabul edildiği tarihten itibaren bir ay içerisinde kaleme aldığını göstermektedir. $\mathrm{Bu}$ durum, hastalığın başlangıcından itibaren yaşamımıza giren yeni tıp terimlerine açılkama getirilmek istendiğine işaret etmektedir. Üren, “Koronavirüs terimleri sözlüğü"nü temel olarak üç başlık (biyoloji ve tıp terimleri, tedaviyle ilgili terimler ve önlemlerle ilgili terimler) altında şekillendirmiştir. Üren'in haber yazısında, bu üç başlık altında şu terimlere yer verilmiştir:

\begin{abstract}
"Biyoloji ve tıp terimleri: bakteri, virüs, patojen, koronavirüs, SARS koronavirüsü, MERS koronavirüsü, SARS-CoV-2, Kovid-19, Enfeksiyon, Hastalık, Zoonotik enfeksiyon, Konak, Vektör, Suş, ACE-2 reseptörü, DNA, RNA, Mutasyon, Pandemi, Epidemi / Tedaviyle ilgili terimler: PCR testi, Ventilatör, Plazma tedavisi, Eştanı, Asemptomatik, Halk sağlı̆̆ı, Epidemiyolog, Virolog, Hakemli yayın / Önlemlerle ilgili terimler: Dezenfekte, Kontaminasyon, Sosyal mesafe, Gönüllü tecrit, Karantina, N-95, Çan eğrisini düzleştirme, Sürü bağışıklı̆̆ı"

(https://www.indyturk.com/node/160731, Erişim tarihi: 14.05.2021).
\end{abstract}

Sık karşılaşılan COVID-19 terimlerinin geniş açıklamalarının, hastalığın salgın ilan edilmesinden itibaren bir ay içerisinde bir gazete haberinde aktarılması ve detaylı açıklamaların yanı sıra, hastalığın seyrini olumlu yönde etkileyecek ek bilgilerin verilmesi -Örneğin, "dezenfekte" teriminin açılamasının ardından "Kendi el dezenfektanınızı yapmak için uygulamanız gerekenleri buradan okuyabilirsiniz" (https://www.indyturk.com/node/160731) bilgisinin aktarılması-önemlidir.

16 Nisan 2020 tarihli, Koronavirüs İle Hayatımıza Giren Terimler bașlıklı haber yazısı da virüsün ortaya çıkışının ardından (üç-dört ay içinde) terimlere ilişsin bilgi ve açıklamaların yapılması ihtiyacına işaret etmektedir. Çavdarcı, "Koronavirüs salgını tüm dünyayı sardığından beri hayatımıza birçok yeni terim girdi. Özellikle sosyal izolasyon sürecinde internet üzerinde bu terimler iyice yayıldı" dedikten sonra "pandemi, filyasyon, entübe, covidiot, covidivorce, doom-scrolling, quaranteens" terimlerini açıklamıştır. Çavdarcl, terimleri açıklarken COVID- 19 ile ilgili diğer bazı bilgilere de yer vermiştir. Örneğin, "pandemi" terimini açıkladıktan sonra, “Koronavirüs hastalığı ise, Aralık 2019'da Çin'in Vuhan şehrinde başlayıp tüm dünyaya yayıldıktan sonra, 11 Mart 2020'de Dünya Sağlık Örgütü tarafından pandemi ilan edildi” (Çavdarcı 2020) bilgisini aktarmıştır.

Özdoğan'ın 25 Ekim 2020 tarihinde yayımlanan Koronavirüs (COVID-19) SÖZLÜĞ̈̈: Bilinmesi gereken 20 terim başlıklı yazısı ise, hastalığın olumlu seyri için anlaşılması büyük önem arz eden bazı terimlerin bilinmesi gerekliliğge vurgu yapmaktadır. Dolayısıyla, hastalığın ortaya çıkışının üzerinden on ay geçtiği halde böyle bir yazının yayımlanması, bazı COVID 19 terimlerinin tam olarak anlaşılmadığına işaret etmektedir. Öyle ki Özdoğan'ın “Herkesin merak ettiği koronavirüsle ilgili terimler” (Özdoğan 2020) ifadesi, bazı terimleri anlaşılır kılma çabası içerisinde olduğuna işaret etmektedir. Yazıda, “Asemptomatik, Bulaşıcı, Coronavirus (koronavirüs), COVID-19, Eğriyi düzleștirme, Epidemi, İnkübasyon (kuluçka) süresi, İzolasyon, Karantina, Kendini karantinaya alma, Kişisel Koruyucu Ekipman (KKE), Pandemi, Salgın (outbreak), SARSCoV-2, Semptom (belirti), Sosyal mesafe, Şüpheli COVID-19, Tarama, Test, Toplum kaynaklı" (Özdoğan

Adres | Address

RumeliDE Dil ve Edebiyat Araşturmalar Dergisi $\quad$ RumeliDE Journal of Language and Literature Studies Osmanağa Mahallesi, Mürver Çiçeği Sokak, No:14/8 Osmanağa Mahallesi, Mürver Çiçeği Sokak, No:14/8 Kadıköy - İSTANBUL / TÜRKIYE 34714 Kadıköy - ISTANBUL / TURKEY 34714 e-posta: editor@rumelide.com e-mail: editor@rumelide.com, tel: +90 505 7958124, +90 2167730616 phone: +90 505 7958124, +90 2167730616 
2020) terimleri açıklanmıştır. Terimlerin açılklamalarının yanı sıra terimlerle veya hastalıkla ilgili bazı önemli bilgilere de yazıda yer verilmiştir: Koronavirüsün yapısının resimle somutlaştırılarak anlatılması; COVID-19 terimi altında, hastalığa neden olan virüsün bilimsel adının "SARS-CoV-2" olduğu bilgisinin verilmesi; hastalığa karşı erken önlem almanın öneminin bir şekil üzerinden somutlaștırılarak anlatılması; “ İnkübasyon (kuluçka) süresi” terimi altında, koronavirüs özelinde kuluçka süresi bilgisinin verilmesi; izolasyon ile ilgili uygulanması gereken stratejilerin aktarılması; "Kendini karantinaya alma" terimi altında, COVID-19 şüphesi durumunda kişinin 14 gün boyunca kendini karantinaya alması gerektiğinin aktarılması; "Kişisel Koruyucu Ekipman (KKE)" terimi altında, virüsten korunmak için hangi maskenin kullanılması gerektiği bilgisinin aktarılması; "SARS-CoV-2" terimi altında, SARS virüsü ile \%80 oranında benzeştiği için bu yeni virüsün adının SARS-CoV-2 olduğu bilgisinin aktarılması; "Semptom (belirti)" terimi açıklandıktan sonra COVID-19 belirtilerinin (ateş, öksürük, nefes darlığı) aktarılması; sosyal mesafenin hastalığın seyrindeki öneminin bir videoğrafi aracılığıyla anlatılması... (Özdoğan 2020)

Zülfikar, COVID-19 nedeniyle gündeme gelen sağlı terimlerden bazılarını şu şekilde sıralamıştır: “Semptom, semptomatik, semptoloji, entübe, minimalize, izole, izolosyon, efektif, karantina, hijyen, hijyenik, viral, vital, deformasyon, dezenfeksiyon, dezenfektan, influence, enfeksiyon, enfeksiyöz, enfektif, enfekte vb. (2020: 10). Zülfikar ayrıca, Türkçede ödünçlenerek kullanılan bazı yabancı kökenli terimlere karşılıklar önermiştir: "influence" terimi için "salgından etkilenmek" , "filyasyon" için "alan taraması - virüs / korona virüs taraması yapmak", "vital bulgu" için "yaşamsal bulgular /hayati bulgular", "mortalite" için "ölüm oranı /kayıp oranı", "vital” için "canlı", "viral” için "virüs kaynaklı", "stabil” için "kararlı, değişmez, sabit, durgun", sosyal sözcüğü yabancı kökenli (social) olduğundan "sosyal mesafe" için "toplumsal aralık / toplumsal mesafe", "kronik" için "süreğen", "pik noktası" için "tepe noktası / doruk noktası", "pik yapmak" için "zirve yapmak", TDK'nin de karşıladığı şekilde "izolasyon" için "yalıtım”, "izole etmek" için "yalıtmak", "izolatör" için "yalıtıcı", "enfeksiyon" için "bulaşma", "enfeksiyöz" için "bulaşkan," "enfekte" için "bulaşmış", "enfekte olmak" için "bulaşmak", "enfektif" için "bulaşıcı", "hijyenik ortam" için "sağlıklı ortam", "pandemik" için "küresel salgın", "pandemi kurulu" yerine "salgın hastalıklar kurulu", "entübe olanlar" yerine "solunum cihazına bağlı olanlar" (Zülfikar 2020).

Terimlerin Türkçe karşılıklarının bulunarak dilde kullanımlarının sağlanması, anlaşılmaya ve Türkçenin gelişimine olumlu yansıyacaktır. Zülfikar’ın aşağıdaki sözleri bu görüşü destekler niteliktedir:

"Söz konusu hastalık dolayısıyla gündeme gelen dezenfektan kelimesine çok isabetli olarak "bulaşmayı bertaraf eder" anlamında bulaşsavar karşılığı verilmiş. Düşünüyorum da aynı sıklıkta bunların Türkçeleri kullanılmış olsaydı Türkçe şimdi çok daha iyi düzeylere gelmiş olacaktı ve anlaşma da o ölçüde kolaylaşacaktı" (Zülfikar 2020: 13).

Yukarıda aktarılanlardan hareketle, COVID-19 terminolojisiyle ilgili bireysel girişimlerde yabancı terimlerin açıklanması ve Türkçe karşılıkların önerilmesiyle, genel olarak, hastalıkla ilgili halkı bilgilendirme ve bilinçlendirme çabası içerisinde olunduğunu söylemek mümkündür.

Türkiye'de, 17 Nisan 2020 tarihinde, Covid-19 Pandemi Değerlendirme Raporu yayımlanmış ve raporda COVID-19 ile ilgili bilgileri paylaşmak üzere "Covid-19 Türkiye Web Portalı" (https:// covid19.tubitak.gov.tr/anasayfa) oluşturulduğu bilgisi aktarılmıştır. Raporda, "Covid-19 Türkiye Web Portalı" üzerinden hastalığa ilişkin terimlere ve açıklamalarına ulaşılabileceği şu sözlerle aktarılmıştır:

"Terminoloji rehberi alt başlı̆̆ında; bulaşıcı hastalıklar ve Covid-19 ile ilgili terimlerin ve açıklamalarının olduğu rehber sunulmaktadır. İndir sekmesine basılarak bu rehbere ulaşllabilir"

(2020: 114, http://www.tuba.gov.tr/files/images/2020/kovidraporu/Covid-19\%20Raporu-Final+.pdf)

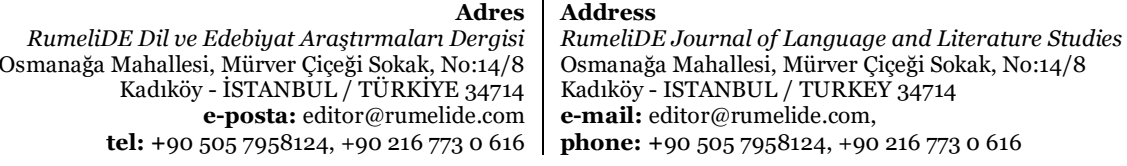


Halk Sağlığı Uzmanları Derneği (HASUDER)'in 27 Mart 2020 tarihli COVID-19 ile ilgili "Kavramlar ve Tanımlar Rehberi”, “Halk Sağlığı Uzmanları Derneği üyelerinin ve sağlık çalışanlarının kullanımına yönelik olarak hazırlanmış olan" bir kllavuzdur. (https://korona. Hasuder .org.tr/wpcontent/uploads/Terminoloji-28.3.2020.pdf). HASUDER COVID-19 Görev Grubu tarafından hazırlanan 11 sayfalık bu raporda, ilk olarak genel kavramlar, ardından COVID-19 özelinde bazı kavramlar açıklanmıştır. Genel kavramlar bölümü altında 43 terim ve açıklamasının yer aldığı görülmektedir. Bu terimlerin, genel olarak tıp alanıyla ilgili olduğu fakat COVID-19 ile birlikte sık kullanılan terimler (epidemi, salgın, sosyal mesafe, maske, vaka, sterilizasyon, semptom, enfeksiyon, fatalite gibi) olduğu söylenebilir. Genel kavramlar arasında sadece "semptom", "filyasyon", "ventilatör" terimlerinin Türkçe karşllıklarıyla sırasıyla "belirti", "saha incelemesi", "solunum cihazı" olarak yer aldığı, diğer batı kökenli terimlerin ise ödünçlenerek batı kökenleriyle aktarıldıkları gözlemlenmiștir. HASUDER'in rehberinde, “Koronavirüs Hastalığı (COVID-19) ile İlgili Kavramlar", "Koronavirüs, COVID-19, COVID-19 için temaslı, COVID-19 için Yakın temaslı, COVID-19 ile uçak temaslı, Olası vaka, Kesin vaka" olarak belirlenmiş ve bu terimlerin açıklamaları yapılmıştır (https://korona. hasuder.org.tr/wp-content/uploads/Terminoloji-28.3.2020.pdf, Erişim tarihi: 15.05.2021). Rehberin kaynakçasında, “T.C. Sağlık Bakanlığı COVID-19 Rehberi”nin yer alması, rehber hazırlanırken bakanlık rehberinin göz önünde bulundurulduğuna ișaret etmektedir. Rehberin esasen sağlık çalışanları için hazırlandığı göz önünde bulundurulduğunda, rehberde daha ziyade sağlık çalışanları için yeni olabilecek veya hastalık için büyük önem arz eden kavramlara değinildiği söylenebilir.

Türkiye'de COVID-19 terminolojisiyle ilgili kurumsal düzeyde yapılan diğer bir düzenleme de T.C. Sağlık Bakanlığı bünyesinde hazırlanan ve kullanıma sunulan “COVID 19 Sözlüğü”dür. "COVID-19 Sözlügü̈, T. C. Sağlık Bakanlı̆̆ı COVID-19 Bilgilendirme Platformu yayınları arasında yer almaktadır (https://covid19.saglik.gov.tr/TR-66394/covid-19-sozlugu.html, Erişim tarihi: 14.05.2021).

Türkiye'de COVID-19 terminolojisiyle ilgili diğer önemli kurumsal çalışmalardan biri de Cumhurbaşkanlığı bünyesinde gerçekleştirilmiştir. Bu bağlamda, Cumhurbaşkanlığı Kültür ve Sanat Politikaları Kurulu tarafından COVID-19 ile ilgili yabancı terimlerin Türkçe karşllıklarını önerilmiştir. Yılmaz, Cumhurbaşkanlığı Kültür ve Sanat Politikaları Kurulu'nun bu önemli girişimini şu sözlerle aktarmaktadır:

“Cumhurbaşkanliği kültür ve sanat politikalari kurulu Türkçelerini önerdi

19.04.2020 tarihinde saat 21.28'de gazete sayfalarında Cumhurbaşkanlığı Kültür ve Sanat Politikaları Kurulu kaynaklı aşağıdaki haber yer aldı:

'... Bu vesileyle bilhassa iletişim vasıtaları dolayısıyla salgın ve koronavirüs konusunda bedensel sağlı̆̆ımıza yönelik konuşma ve tavsiyeleriyle bizleri aydınlatan hekimlerimiz ve bilim insanlarımızdan -binlerce şükranımızı yineleyerek- kültürel sağlığımız söz konusu olduğunda da güzel dilimizin imkânlarını kullanmalarını, Cumhurbaşkanlığı Kültür ve Sanat Politikaları Kurulu adına hassaten rica ediyor, konuya ilişkin lügatçeyi saygıyla sunuyoruz: "pandemi" yerine "salgın", "bulaş" yerine "bulaşı", "peak" yerine "zirve", "entübe" yerine "solunum", "droplet" yerine "damlacık", "immün" yerine "bağışıklık", "pnömoni" yerine "zatürre", "filyasyon" yerine"türevi,türevsel"..."

(https://www.facebook.com/groups/50794706990/posts/10156638737476991, Erişim tarihi: 16.05.2021)

Görüldüğü üzere, COVID-19 terminolojisi sorunlarının çözümü için, Türkiye'de bireysel ve kurumsal bazı girişimler olmuş ve bu doğrultuda bazı terminolojik düzenlemeler yapılmıştır.

\section{Türk yazılı basınında COVID-19 terimleri}

$\mathrm{Bu}$ bölümde, Türkiye'deki gazete haberlerinde geçen COVID-19 terimleri, Türkiye'deki COVID-19 terminolojisi ile ilgili düzenlemeler öncesi ve sonrası olmak üzere, iki dönemde ele alınmaktadır. Hastalıkla

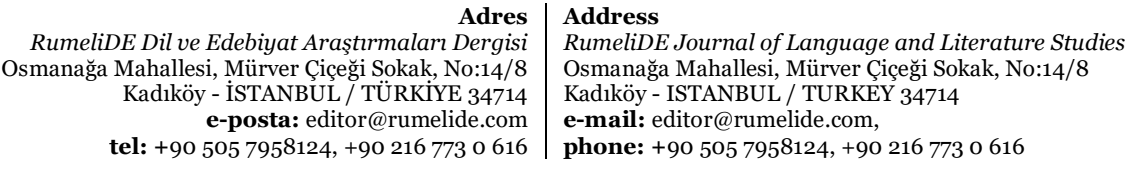


ilgili bilgilerin halk tarafından tam ve doğru anlaşılmasının büyük önem arz etmesi sebebiyle, gazete haber metinlerinde geçen terimlerin değerlendirilmesinde öncelikli olarak başvurulacak belirtim değerlendirme ölçütlerinin çalışmanın birinci bölümünde de belirtildiği gibi "Hedef kitleye uygunluk", "Açılklk", "DilselMantıksal Doğruluk" ve "Türetilebilirlik / Çekilebilirlik" olarak belirlenmesine karar verilmiştir. Illk olarak, hastalığın belirmesinden itibaren ilk üç ay içerisinde yayımlanan gazete haber örneklerinde geçen terimler yukarıda belirtilen ölçütlere göre değerlendirilmekte, ardından Türkiye'deki bazı terminolojik düzenlemeler sonrası dönemde yayımlanan haber örneklerindeki terimler ilgili ölçütlere göre değerlendirilmektedir. Milliyet Gazetesi'nin 30 Ocak 2020 tarihli haberinde, COVID-19'un "Çin'in Hubey Eyaleti'ne bağlı Wuhan kentinde 12 Aralık 2019'da ortaya çık”tığı aktarılmıştır. (https://www.milliyet.com.tr/gundem/turkler-ambulans-ucakla-getirilecek-6132862 ${ }_{2}$ Erişim tarihi: 20.05.2021). Bu nedenle, çalışmamızda, COVID-19 terminolojisiyle ilgili girişim ve düzenlemeler öncesi dönem, Aralık 2019 ile Mart 2020 arası dönem olarak belirlenmiştir zira Türkiye'de kurum ve kuruluşlarca sorunların çözümüne yönelik terminolojik girişimlerin özellikle Mart - Nisan 2020 arasında gelişim gösterdiği gözlemlenmiştir. (Bknz: T.C. Sağlık Bakanlığı COVID-19 Sözlüğü, Cumhurbaşkanlığı Kültür ve Sanat Politikaları Kurulu'nca COVID-19 terimlerine önerilen Türkçe karşlıklar vb.). COVID-19 terminolojisiyle ilgili girișim ve düzenlemeler sonrası dönem ise Mayıs 2020'den günümüze kadarki dönem olarak belirlenmiştir. Yapılan terminolojik düzenlemelerin duyurulması ve uygulamaya geçirilmesi için düzenlemeler sonrasında bir aylık bir sürenin geçmesi beklenebilir. Bu nedenle, terminolojik düzenleme sonrası dönem Mayıs 2020 sonrası olarak belirlenmiştir.

\subsection{Türkiye'deki COVID-19 terminolojisiyle ilgili düzenlemeler öncesinde COVID-19 terimlerinin gazete haberlerinde kullanımı}

Çalışmamızda COVID-19 terimlerinin basındaki kullanımlarını incelemek için Türkiye'deki yüksek tirajlı beş gazeteye (Hürriyet, Sabah, Sözcü, Posta, Milliyet) (https://journo.com.tr/tirajlar-2020) başvuracağımız bilgisini daha önce (giriş bölümünde) aktarmıștık. Bu alt başlıkta, COVID-19 terimlerinin Türkiye'deki terminolojik düzenlemeler öncesinde nasıl kullanıldıklarını görebilmek için, adı geçen gazetelerin - Aralık 2019 sonundan Mart 2020 sonuna kadarki sürede yayımlanan- COVID-19 ile ilgili haber örneklerine başvurulacaktır. Bu doğrultuda, yukarıda adı geçen gazetelerden alınan bazı haber başlıkları aşağıda listelenmiş, ardından bu haberlerde geçen COVID-19 terimleri tablo halinde sunulmuştur.

\section{Gazetelerde yer alan COVID-19 ile ilgili bazı haber başlıkları:}

• “Çin'de SARS salgını şüphesi”, 02.01.2020 tarihli Hürriyet Gazetesi haberi

- “Kocaeli İl Sağlı Müdürlüğü'nden 'koronavirüs' açılaması”, 30.01.2020 tarihli Hürriyet Gazetesi haberi

- "ABD, koronavirüs tehdidi nedeniyle "acil durum" ilan etti", 01.02.2020 tarihli Hürriyet Gazetesi haberi

- "Son dakika haberler... Ve korkulan oldu! Avrupa'da korona virüs kaynaklı ilk ölüm”, 15.02.2020 tarihli Hürriyet Gazetesi haberi

- "Japonya'dan Kovid-19 ile mücadele için 2,5 milyar dolarlık paket", 29.02.2020 tarihli Hürriyet Gazetesi haberi

- “Corona Virüs bilgilendirme broşürü 81 ile gönderildi", 02.03.2020 tarihli Hürriyet Gazetesi haberi

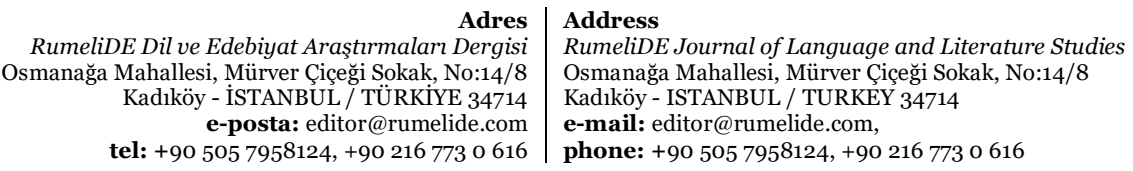


• "Koronavirüs kaygısını çocuklarınıza hissettirmeyin”, 16.03.2020 tarihli Hürriyet Gazetesi haberi

- “İyileşmiş hastanın kanıyla Corona Virüs tedavisi Türkiye'de de başlıyor”, 31.03 .2020 tarihli Hürriyet Gazetesi haberi

- "Sağlık Bakanı Koca: Şu an Türkiye için herhangi bir koronavirüsü riski söz konusu değil”, 22.01.2020 tarihli Sabah Gazetesi haberi

- “Corona virüsü nedir, belirtileri nasıl fark edilir? Çin'de ortaya çıkan Koronavirüs tedavisi var mı? İște bilinmesi gerekenler”, 31.01.2020 tarihli Sabah Gazetesi haberi

- (Koronavirüs) Kovid-19 dünyada 73 binden fazla kişiye bulaştı", 18.02.2020 tarihli Sabah Gazetesi haberi

- Koronavirüs hakkında doğru bilinen yanlışlar!”, 28.02.2020 tarihli Sabah Gazetesi haberi

- Sağlık Bakanlığı Bilim Kurulundan "koronavirüs" broşürü", 02.03.2020 tarihli Sabah Gazetesi haberi

• “10 soruda koronavirüs! İşte koronavirüs ile ilgili bilmeniz gerekenler...,”, 13.03.2020 tarihli Sabah Gazetesi haberi

- "Salgın korkusu varolan psikiyatrik hastalıkları tetikliyor", 31.03.2020 Sabah Gazetesi haberi

• “İ.Ü.C. Cerrahpaşa Tıp Fakültesi'nin Corona virüsü raporu ortaya çıktı!”, 31.01.2020 tarihli Sözcü Gazetesi haberi

- “Corona virüsünden korunmanın 4 yolu! Enfeksiyon Hastalıkları Uzmanı belirtileri anlattı", 01.02.2020 tarihli Sözcü Gazetesi haberi

- Corona uyarısı yapan ve susturulmak istenen doktora da virüs bulaştı!”, 04.02.2020 tarihli Sözcü Gazetesi haberi

• “Koronavirüs nesnelerin üzerinde ne kadar süre yaşayabilir?”, 14.02.2020 tarihli Sözcü Gazetesi haberi

• “Prof. Dr. Çolak: Koronavirüs yayılma hızı azalacak çünkü...”, 03.03.2020 tarihli Sözcü Gazetesi haberi

- "Yeni koronavirüs enfeksiyonunu teşhis edebiliyor muyuz? Olası bir salgına hazır mıyız?", 10.03.2020 tarihli Sözcü Gazetesi haberi

• “Corona virüsü nedeniyle karantinaya alınan il, ilçe, mahalle ve köyler...” , 29.03.2020 tarihli Sözcü Gazetesi haberi.

• Çin'de ortaya çıkan virüs, tüm dünyaya yayılabilir”, 16.01.2020 tarihli Posta Gazetesi haberi

- “Bakan Koca'dan coronavirüs açıklaması”, 31.01.2020 tarihli Posta Gazetesi haberi

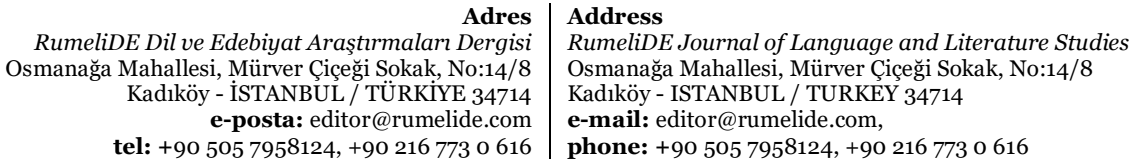
tel: +90 $5057958124,+902167730616$ 
- "Bakan Koca: Ülkemizde koronavirüs tanısı alan vatandaşımız yok", 02.02.2020 tarihli Posta Gazetesi haberi

- “Dünya Sağlık Örgütü'nden hükümetlere koronavirüs çağrısı: Hazırlıklı olun”, 16.02 .2020 tarihli Posta Gazetesi haberi

- Metrobüs ve duraklara koronavirüs temziliği", 29.02.2020 tarihli Posta Gazetesi haberi

- “Türkiye, koronavirüs için etkin önlemler aldı", 13.03.2020 tarihli Posta Gazetesi haberi

- "Metrobüs ve duraklara koronavirüs temziliği", 29.02.2020 tarihli Posta Gazetesi haberi

- "Son dakika... Türkiye'de corona virüsten ölenlerin sayısı 214'e yükseldi", 31.03 .2020 tarihli Posta Gazetesi haberi

- “Türkler ambulans uçakla getirilecek", 31.01.2020 tarihli Milliyet Gazetesi haberi

- “Operasyon tamam! Ankara'daki 14 günlük karantina başladı”, 02.02.2020 tarihli Milliyet Gazetesi haberi

- "Koronavirüs sonrası şirketler tek tek açıkladı! Onlarca mağaza kapandı", 17.02 .2020 tarihli Milliyet Gazetesi haberi

- "Son dakika... Koronavirüste şok dalgaları! Azerbaycan'da ilk vaka ortaya çıktı", 28.02.2020 tarihli Milliyet Gazetesi haberi

- "Son dakika | En yetkili isimden şoke eden koronavirüs açıklaması! İşte tehlikede olan 4 ülke...", 03.03.2020 tarihli Milliyet Gazetesi haberi

- “Bugün corona virüsü vaka sayısı ve ölü sayısı kaç? Türkiye'de corona virüsü tablosu”, 31. 03.2020 tarihli Milliyet Gazetesi haberi

Aşağıdaki tablo, sadece yukarıda başlğ̆ı geçen haberlerdeki COVID-19 terimlerini kapsamaktadır.

Tablo 1: Türkiye'deki terminolojik düzenlemeler öncesinde bazı gazete haberlerinde geçen COVID-19 Terimleri

\begin{tabular}{|c|c|c|}
\hline $\begin{array}{l}\text { Gazete haberlerinde geçen } \\
\text { COVID-19 terimleri }\end{array}$ & \multicolumn{2}{|c|}{ Terimin geçtiği gazetenin adı ve haberin tarihi } \\
\hline Koronavirüs & \multicolumn{2}{|c|}{$\begin{array}{l}\text { Hürriyet 30.01.2020; 01.02.2020; } 16.03 .2020 \text { / Sabah 22.01.2020; } 18.02 .2020 \text {; } \\
\text { 28.02.2020; 02.03.2020; 13.03.2020 / Sözcü 14.02.2020; 03.03.2020 / Posta } \\
\text { 16.01.2020; 16.02.2020; 29.02.2020; } 13.03 .2020 \text { / Milliyet 30.01.2020; } \\
\text { 03.03.2020; 17.02.2020; 28.02.2020 tarihli haberleri }\end{array}$} \\
\hline Korona Virüs & \multicolumn{2}{|c|}{ Hürriyet 15.02.2020 / Posta 02.02.2020 / Milliyet 17.02.2020 tarihli haberleri } \\
\hline Korona & \multicolumn{2}{|c|}{ Sabah 13.03.2020 tarihli haberi } \\
\hline Korona Virüsü & \multicolumn{2}{|c|}{ Milliyet 30.01.2020 tarihli haberi } \\
\hline Corona Virüs & \multicolumn{2}{|c|}{ Hürriyet 31.03.2020 tarihli haberi } \\
\hline corona virüs & \multicolumn{2}{|c|}{ Posta 31.03.2020 tarihli haberi } \\
\hline Corona Virüsü & \multicolumn{2}{|c|}{$\begin{array}{l}\text { Sabah 31.01.2020 / Sözcü 31.01.2020; 01.02.2020; 04.02.2020; 29.03.2020 / } \\
\text { Milliyet 31.03.2020 tarihli haberleri }\end{array}$} \\
\hline \multicolumn{2}{|c|}{$\begin{array}{r}\text { Adres } \\
\text { RumeliDE Dil ve Edebiyat Arasttrmaları Dergisi } \\
\text { Osmanağa Mahallesi, Mürver Cičĕgi Sokak, No:14/8 } \\
\text { Kadı̈̈y - İSTANBUL / TÜRKIYE } 34714 \\
\text { e-posta: editor@rumelide.com } \\
\text { tel: }+90 \text { 505 7958124, +90 } 216773 \text { o } 616\end{array}$} & $\begin{array}{l}\text { Address } \\
\text { RumeliDE Journal of Language and Literature Studies } \\
\text { Osmanağa Mahallesi, Mürver Cicceği Sokak, No:14/8 } \\
\text { Kadıköy - ISTANBUL / TURKEY } 34714 \\
\text { e-mail: editor@ @rumelide.com, } \\
\text { phone: +90 505 7958124, +90 } 216773 \text { o } 616\end{array}$ \\
\hline
\end{tabular}


538 / RumeliDE Journal of Language and Literature Studies 2021.S9 (August)

COVID-19 Terms in Turkish print media: problems and solution suggestions / A. Turan; C. Ylldırım (pp. 525-551)

\begin{tabular}{|c|c|}
\hline Corona Virisü (Koronavirüs) & Sözcü 01.02.2020 tarihli haberi \\
\hline Korona Virüs (COVID19) & Hürriyet 15.02.2020 tarihli haberi \\
\hline Koronavirüs (COVID-19) & Hürriyet 16.03.2020 / Sabah 31.01.2020 tarihli haberleri \\
\hline Koronavirüs (Covid-19) & Sabah 28.02.2020 / Sözcü 03.03.2020 tarihli haberleri \\
\hline (Koronavirüs) Kovid-19 & Sabah 18.02.2020 tarihli haberi \\
\hline Koronavirüs (Kovid-19) & $\begin{array}{l}\text { Sabah 18.02.2020; 02.03.2020; 31.03.2020 / Posta 16.02.2020 / Milliyet } \\
\text { 28.02.2020 tarihli haberleri }\end{array}$ \\
\hline Coronavirüs & Sabah 31.01.2020 / Sözcü 14.02.2020 / Posta 31.01.2020 tarihli haberleri \\
\hline Kovid-19 & Hürriyet 29.02.2020 / Posta 13.03.2020; 31.03 .2020 tarihli haberleri \\
\hline Covid-19 & Hürriyet 31.03.2020 / Milliyet 28.02.2020 tarihli haberleri \\
\hline Covid-19 & Sözcü 14.02.2020 tarihli haberi \\
\hline Koronavirüs (Kovid-19) & Hürriyet 29.02.2020 tarihli haberi \\
\hline Corona Virüs (Kovid-19) & Hürriyet 02.03.2020 tarihli haberi \\
\hline Corona Virüs & Hürriyet 02.03.2020 tarihli haberi \\
\hline İnfluenza Virüsü & Sabah 22.01.2020 tarihli haberi \\
\hline Kovid-19 Tedavisi & Posta 31.03.2020 tarihli haberi \\
\hline Koronavirüs Hastalığl & Sabah 13.03.2020 /Sözcü 10.03.2020 tarihli haberleri \\
\hline Koronavirüs Vakası & Posta 02.02.2020 / Sözcü 03.03.2020 / Milliyet 28.02.2020 tarihli haberleri \\
\hline Koronavirüs (Kovid-19) Vakası & Milliyet 28.02.2020 tarihli haberi \\
\hline Corona Virüsü Vaka Sayısı & Milliyet 31.03.2020 tarihli haberi \\
\hline Pozitif Vaka & Posta 31.03.2020 tarihli haberi \\
\hline Covid-19 (Koronavirüs) Aşııı & Milliyet 03.03.2020 tarihli haberi \\
\hline Koronavirüs Tanısı & Posta 02.02.2020 / Milliyet 02.02.2020 tarihli haberleri \\
\hline Corona Virüs Tanısı & Posta 31.03.2020 tarihli haberi \\
\hline Koronavirüs Salgını & $\begin{array}{l}\text { Hürriyet 01.02.2020 / Posta 29.02.2020 / Milliyet 02.02.2020; 17.02.2020; } \\
\text { 03.03.2020 tarihli haberleri }\end{array}$ \\
\hline Korona Virüs Salgını & Milliyet 17.02.2020 tarihli haberi \\
\hline Koronavirüs (Kovid-19) Salgını & Hürriyet 29.02.2020 / Sabah 31.03.2020 tarihli haberleri \\
\hline Korona Virüs (Kovid-19) Salgını & Sözcü 29.03.2020 tarihli haberi \\
\hline
\end{tabular}

Adres $\mid$ Address

RumeliDE Dil ve Edebiyat Araştrrmaları Dergisi $\quad$ RumeliDE Journal of Language and Literature Studies Osmanağa Mahallesi, Mürver Çiçeği Sokak, No:14/8 $\quad$ Osmanağa Mahallesi, Mürver Çiçeği Sokak, No:14/8

Kadıköy - ISTANBUL / TURKIYE 34714 Kadıö̈y - ISTANBUL / TURKEY 34714

e-posta: editor@rumelide.com $\quad$ e-mail: editor@rumelide.com,

tel: +90 $5057958124,+90216773$ o 616 phone: +90 505 7958124, +90 216773 o 616 


\begin{tabular}{|c|c|}
\hline Koronavirüs (COVID-19) Salgını & Hürriyet 16.03.2020 tarihli haberi \\
\hline Corona Virüs Salgını & Hürriyet 31.03.2020 /Sözcü 30.01.2020 tarihli haberleri \\
\hline Corona Virüs Salgını & Sözcü 04.02.2020 tarihli haberi \\
\hline Corona Virüsü Salgını & Sözcü 29.03.2020 tarihli haberi \\
\hline Kovid-19 Salgını & Sabah 18.02.2020 / Posta 16.02.2020 tarihli haberleri \\
\hline Salgin & $\begin{array}{l}\text { Hürriyet 01.02.2020; 31.03.2020 / Sabah 22.01.2020; 31.01.2020; 13.03.2020; } \\
\text { 31.03.2020 / Sözcü 10.03.2020; 29.03.2020 / Posta 16.01.2020; 16.02.2020 / } \\
\text { Milliyet 03.03.2020 tarihli haberleri }\end{array}$ \\
\hline SARS Salgını & Sözcü 04.02.2020 tarihli haberi \\
\hline $\begin{array}{l}\text { Şiddetli Akut Solunum Yolu } \\
\text { Sendromuna (SARS) Salgını }\end{array}$ & Posta 16.01.2020 tarihli haberi \\
\hline Korku Salgını & Sabah 31.03.2020 tarihli haberi \\
\hline Koronavirüs Pozitif Olgusu & Sözcü 03.03.2020 tarihli haberi \\
\hline Enfeksiyon & $\begin{array}{l}\text { Hürriyet 15.02.2020; 02.03.2020; 31.03.2020 / Sabah 31.01.2020; 28.02.2020; } \\
\text { 02.03.2020; 31.03.2020 / Sözcü 03.03.2020; 31.01.2020 / Posta 16.01.2020; } \\
\text { 30.01.2020 / Milliyet 02.02.2020 tarihli haberleri }\end{array}$ \\
\hline Koronavirüs Enfeksiyonu & Sözcü 10.03.2020 tarihli haberi \\
\hline 2019-Ncov Enfeksiyonu & Sözcü 31.01.2020 tarihli haberi \\
\hline $\begin{array}{l}\text { Yaygın Üst Solunum Yolu } \\
\text { Enfeksiyonu }\end{array}$ & Posta 29.02.2020 tarihli haberi \\
\hline Solunum Yolu Enfeksiyonu & Sözcü 31.01.2020 / Posta 02.02.2020 tarihli haberleri \\
\hline Enfekte Olmuş Kişi & Sözcü 14.02.2020 tarihli haberi \\
\hline Enfekte Olan & Milliyet 30.01.2020 tarihli haberi \\
\hline Damlacık Enfeksiyonu & Sabah 28.02.2020 tarihli haberi \\
\hline Karantina & $\begin{array}{l}\text { Hürriyet 30.01.2020; 01.02.2020 / Sabah 22.01.2020 / Sözcü 04.02.2020; } \\
\text { 29.03.2020 / Posta 13.03.2020 / Milliyet 30.01.2020; 02.02.2020 tarihli haberleri }\end{array}$ \\
\hline Karantina Süreci & Milliyet 02.02.2020 tarihli haberi \\
\hline Karantina Bölgesi & Milliyet 30.01.2020 tarihli haberi \\
\hline Karantinaya Alınmak & Milliyet 28.02.2020 tarihli haberi \\
\hline Karantina Altında Tutulmak & Milliyet 30.01.2020; 02.02.2020 tarihli haberleri \\
\hline İzolasyon & Hürriyet 30.01.2020 / Sabah 31.03.2020 / Sözcü 29.03.2020 tarihli haberleri \\
\hline İzole Edilen & Sabah 31.01.2020 tarihli haberi \\
\hline Sosyal İzolasyon & Sabah 31.03.2020 tarihli haberi \\
\hline İzole Koşullar & Milliyet 30.01.2020 tarihli haberi \\
\hline Epidemiyoloji & Hürriyet 30.01.2020 tarihli haberi \\
\hline Epidemik & Sabah 28.02.2020 tarihli haberi \\
\hline
\end{tabular}

RumeliDE Dil ve Edebiyat Araşttrmalar Dergisi $\quad$ RumeliDE Journal of Language and Literature Studies Osmană̆a Mahallesi, Mürver Ciçeği Sokak, No:14/8 $\quad$ Osmanağa Mahallesi, Mürver Çiçeği Sokak, No:14/8

Kadıköy - ISTANBUL / TURKIYE 34714 Kadıö̈y - ISTANBUL / TURKEY 34714

e-posta: editor@rumelide.com $\quad$ e-mail: editor@rumelide.com,

tel: +90 $5057958124,+90216773$ o 616 phone: +90 505 7958124, +90 216773 o 616 
540 / RumeliDE Journal of Language and Literature Studies 2021.S9 (August)

COVID-19 Terms in Turkish print media: problems and solution suggestions / A. Turan; C. Ylldırım (pp. 525-551)

\begin{tabular}{|c|c|c|}
\hline Hijyen & \multicolumn{2}{|c|}{$\begin{array}{l}\text { Hürriyet 30.01.2020; 02.03.2020 / Sabah 22.01.2020; 28.02.2020; 02.03.2020 / } \\
\text { Sözcü 01.02.2020 tarihli haberleri }\end{array}$} \\
\hline Damlacık & \multicolumn{2}{|c|}{$\begin{array}{l}\text { Hürriyet 02.03.2020 / Sabah 28.02.2020; 02.03.2020; } 13.02 .2020 \text { / Sözcü } \\
\text { 03.03.2020; 31.01.2020 / Posta 02.02.2020 tarihli haberleri }\end{array}$} \\
\hline Belirti & \multicolumn{2}{|c|}{$\begin{array}{l}\text { Hürriyet 02.03.2020 / Sabah 22.01.2020; 31.01.2020; 28.02.2020; } 13.03 .2020 \text {; } \\
\text { 31.03.2020 / Sözcü 03.03.2020; 01.02.2020 / Posta 31.01.2020 / Milliyet } \\
\text { 30.01.2020; 02.02.2020 tarihli haberleri }\end{array}$} \\
\hline Semptom & \multicolumn{2}{|c|}{$\begin{array}{l}\text { Hürriyet 31.03.2020 / Sabah 31.01.2020; 28.02.2020 / Sözcü 31.01.2020 tarihli } \\
\text { haberleri }\end{array}$} \\
\hline Zatürre & \multicolumn{2}{|c|}{ Hürriyet 02.03.2020 / Sabah 28.02.2020 / Sözcü 01.02.2020 tarihli haberleri } \\
\hline Pnömoni & \multicolumn{2}{|c|}{ Sabah 31.01.2020 / Sözcü 31.01.2020 tarihli haberleri } \\
\hline Pnömoni (Zatürre) & \multicolumn{2}{|c|}{ Sözcü 31.01.2020 tarihli haberi } \\
\hline Zatürre Virüsü & \multicolumn{2}{|c|}{ Posta 16.01.2020 tarihli haberi } \\
\hline Solunum Yetmezliği & \multicolumn{2}{|c|}{ Sözcü 01.02.2020 tarihli haberi } \\
\hline Solunum Enfeksiyonu & \multicolumn{2}{|c|}{ Posta 02.02.2020 tarihli haberi } \\
\hline Kuluçka Süresi & \multicolumn{2}{|c|}{ Hürriyet 02.03.2020 / Sabah 02.03.2020 / Milliyet 30.01.2020 tarihli haberleri } \\
\hline Antiseptik & \multicolumn{2}{|c|}{ Hürriyet 02.03.2020 / Sabah 02.03.2020 tarihli haberleri } \\
\hline Bulaşma & \multicolumn{2}{|c|}{ Hürriyet 16.03.2020 tarihli haberi } \\
\hline Bulaşıcı Hastalık & \multicolumn{2}{|c|}{ Posta 31.01.2020 tarihli haberi } \\
\hline Anksiyete & \multicolumn{2}{|c|}{ Hürriyet 16.03.2020 / Sabah 31.03.2020 tarihli haberleri } \\
\hline Dezenfektan & \multicolumn{2}{|c|}{$\begin{array}{l}\text { Hürriyet } 16.03 .2020 \text { / Sabah 28.02.2020; } 13.03 .2020 ; 31.03 .2020 \text { tarihli } \\
\text { haberleri }\end{array}$} \\
\hline Dezenfeksiyon & \multicolumn{2}{|c|}{ Sözcü 14.02.2020 / Posta 29.02.2020 tarihli haberleri } \\
\hline El Dezenfeksiyon Cihazı & \multicolumn{2}{|c|}{ Posta 29.02.2020 tarihli haberi } \\
\hline Dezenfeksiyon Araçları & \multicolumn{2}{|c|}{ Sözcü 14.02.2020 tarihli haberi } \\
\hline Dezenfekte İşlemi & \multicolumn{2}{|c|}{ Milliyet 02.02.2020 tarihli haberi } \\
\hline Dezenfekte Etmek & \multicolumn{2}{|c|}{$\begin{array}{l}\text { Sözcü 14.02.2020; 03.03.2020 / Posta 29.02.2020 / Milliyet 03.03.2020 tarihli } \\
\text { haberleri }\end{array}$} \\
\hline İnaktivasyon Stratejileri & \multicolumn{2}{|c|}{ Sözcü 14.02.2020 tarihli haberi } \\
\hline Ultraviole & \multicolumn{2}{|c|}{ Sözcü 03.03.2020 tarihli haberi } \\
\hline Anti Bakteriyel Sprey & \multicolumn{2}{|c|}{ Hürriyet 16.03.2020 tarihli haberi } \\
\hline Plazma Kan & \multicolumn{2}{|c|}{ Hürriyet 31.03 .2020 tarihli haberi } \\
\hline Plazma Bağıșı & \multicolumn{2}{|c|}{ Hürriyet 31.03.2020 tarihli haberi } \\
\hline Pasif Antikor & \multicolumn{2}{|c|}{ Hürriyet 31.03.2020 tarihli haberi } \\
\hline Start Vermek & \multicolumn{2}{|c|}{ Hürriyet 31.03.2020 tarihli haberi } \\
\hline $\begin{array}{r}\text { RumeliDE } D \\
\text { Osmanağa Mał } \\
\text { Kac } \\
\text { tel: }\end{array}$ & $\begin{array}{r}\text { Adres } \\
\text { ebiyat Araştrmaları Dergisi } \\
\text { Iürver Çiçeği Sokak, No:14/8 } \\
\text { STANBUL / TÜRKIYYE 34714 } \\
\text { osta: editor@rumelide.com } \\
7958124,+90216773 \text { o } 616\end{array}$ & $\begin{array}{l}\text { Address } \\
\text { RumeliDE Journal of Language and Literature Studies } \\
\text { Osmanağa Mahallesi, Mürver Cicceği Sokak, No:14/8 } \\
\text { Kadıöy - ISTANBUL / TURKEY } 34714 \\
\text { e-mail: editor@rumelide.com, } \\
\text { phone: +90 505 7958124, +90 } 216773 \text { o } 616\end{array}$ \\
\hline
\end{tabular}




\begin{tabular}{|c|c|c|}
\hline Donör & \multicolumn{2}{|c|}{ Hürriyet 31.03.2020 tarihli haberi } \\
\hline Antikor & \multicolumn{2}{|c|}{ Hürriyet 31.03.2020 tarihli haberi } \\
\hline Korona Bilim Kurulu & \multicolumn{2}{|c|}{ Hürriyet 31.03.2020 tarihli haberi } \\
\hline Plazma Transfüzyon & \multicolumn{2}{|c|}{ Hürriyet 31.03.2020 tarihli haberi } \\
\hline Know How & \multicolumn{2}{|c|}{ Hürriyet 31.03.2020 tarihli haberi } \\
\hline Preparat & \multicolumn{2}{|c|}{ Hürriyet 31.03.2020 tarihli haberi } \\
\hline Mutasyon & \multicolumn{2}{|c|}{$\begin{array}{l}\text { Hürriyet 31.03.2020 / Sabah 22.01.2020; } 13.03 .2020 \text { / Sözcü 03.03.2020 tarihli } \\
\text { haberleri }\end{array}$} \\
\hline Pasif İmmünizasyon (Bağışıklık) & \multicolumn{2}{|c|}{ Hürriyet 31.03.2020 tarihli haberi } \\
\hline Pandemi (Küresel Salgın) & \multicolumn{2}{|c|}{ Hürriyet 31.03.2020 tarihli haberi } \\
\hline Pandemik & \multicolumn{2}{|c|}{ Sabah 28.02.2020 tarihli haberi } \\
\hline Endemi (Bölgesel Salgın) & \multicolumn{2}{|c|}{ Hürriyet 31.03.2020 tarihli haberi } \\
\hline Endemik & \multicolumn{2}{|c|}{ Sabah 28.02.2020 tarihli haberi } \\
\hline PCR Test & \multicolumn{2}{|c|}{ Hürriyet 31.03 .2020 tarihli haberi } \\
\hline Antiviral Ajan & \multicolumn{2}{|c|}{ Sabah 22.01.2020 tarihli haberi } \\
\hline Termal Kamera & \multicolumn{2}{|c|}{ Sabah 22.01.2020 / Posta 31.01.2020; 13.03 .2020 tarihli haberleri } \\
\hline Bronşalveoler Lavaj Sıvısı & \multicolumn{2}{|c|}{ Sözcü 31.01.2020 tarihli haberi } \\
\hline Genom Analizi & \multicolumn{2}{|c|}{ Sözcü 31.01.2020 tarihli haberi } \\
\hline SARS Virüsü & \multicolumn{2}{|c|}{ Hürriyet 02.01.2020 tarihli haberi } \\
\hline SARS-Cov & \multicolumn{2}{|c|}{ Sabah 31.01.2020 tarihli haberi } \\
\hline Spektrum & \multicolumn{2}{|c|}{ Sabah 31.01.2020 tarihli haberi } \\
\hline $\begin{array}{l}\text { Ciddi Akut Solunum Sendrouna } \\
\text { (Severe Acute Respiratory } \\
\text { Syndrome, SARS }\end{array}$ & \multicolumn{2}{|c|}{ Sabah 31.01.2020 tarihli haberi } \\
\hline $\begin{array}{l}2003 \text { Sars (Şiddetli Akut } \\
\text { Solunum Yolu Sendromu) }\end{array}$ & \multicolumn{2}{|c|}{ Sabah 28.02.2020 tarihli haberi } \\
\hline $\begin{array}{l}\text { Ağır Akut Solunum Sendromu } \\
\text { (Sars) }\end{array}$ & \multicolumn{2}{|c|}{ Sözcü 14.02.2020 tarihli haberi } \\
\hline SARS-Cov & \multicolumn{2}{|c|}{ Sözcü 31.01.2020 tarihli haberi } \\
\hline 2019-Ncov & \multicolumn{2}{|c|}{ Sözcü 31.01.2020 tarihli haberi } \\
\hline $\begin{array}{l}\text { Endemik İnsan Coronavirüsü } \\
\text { (Hcov) }\end{array}$ & \multicolumn{2}{|c|}{ Sözcü 14.02.2020 tarihli haberi } \\
\hline Bulgu & \multicolumn{2}{|c|}{ Sabah 31.01.2020 tarihli haberi } \\
\hline Yakın Temas & \multicolumn{2}{|c|}{ Sabah 28.02.2020 tarihli haberi } \\
\hline $\begin{array}{r}\text { RumeliDE Dil ve Ed } \\
\text { Osmanağa Mahallesi, } \\
\text { Kadıköy }- \\
\text { e- } \\
\text { tel: }+9050\end{array}$ & $\begin{array}{r}\text { Adres } \\
\text { Ebiyat Araşturmaları Dergisi } \\
\text { Iürver Çiçeği Sokak, No:14/8 } \\
\text { STANBUL / TÜRKIYYE 34714 } \\
\text { osta: editor@rumelide.com } \\
7958124,+90216773 \text { o } 616\end{array}$ & $\begin{array}{l}\text { Address } \\
\text { RumeliDE Journal of Language and Literature Studies } \\
\text { Osmanağa Mahallesi, Mürver Cicceği Sokak, No:14/8 } \\
\text { Kadiköy - ISTANBUL / TURKEY } 34714 \\
\text { e-mail: editor@rumelide.com, } \\
\text { phone: +90 505 7958124, +90 } 216773 \text { o } 616\end{array}$ \\
\hline
\end{tabular}


542 / RumeliDE Journal of Language and Literature Studies 2021.S9 (August)

COVID-19 Terms in Turkish print media: problems and solution suggestions / A. Turan; C. Yıldırım (pp. 525-551)

\begin{tabular}{|c|c|}
\hline Nüksetme & Sabah 31.03.2020 tarihli haberi \\
\hline Obsesif Kompulsif & Sabah 31.03.2020 tarihli haberi \\
\hline Sterilizasyon & Sabah 31.03.2020 tarihli haberi \\
\hline İnhalasyon & Sabah 31.03.2020 tarihli haberi \\
\hline Toksik & Sabah 31.03.2020 tarihli haberi \\
\hline Solüsyon & Sözcü 14.02.2020 tarihli haberi \\
\hline Sürveyans Sistemi & Sözcü 31.01.2020 tarihli haberi \\
\hline İnkübasyon Süresi & Sözcü 31.01.2020 tarihli haberi \\
\hline Bulaştırıcılık Süresi & Sözcü 31.01.2020 tarihli haberi \\
\hline Dispne (Solunum Güçlüğü) & Sözcü 31.01.2020 tarihli haberi \\
\hline $\begin{array}{l}\text { Agir Akut Solunum Yolu } \\
\text { Enfeksiyonu }\end{array}$ & Sözcü 31.01.2020 tarihli haberi \\
\hline Fatalite (Öldürücülük) & Sözcü 31.01.2020 tarihli haberi \\
\hline Solunum Yolu Patojenleri & Sözcü 31.01.2020 tarihli haberi \\
\hline Ko-Enfeksiyonları & Sözcü 31.01.2020 tarihli haberi \\
\hline Tanı Testi & Sözcü 10.03.2020 tarihli haberi \\
\hline Yerli Tanı Kiti & Posta 13.03.2020 tarihli haberi \\
\hline İnfluenza & Sözcü 10.03.2020 / Posta 16.01.2020 tarihli haberleri \\
\hline $\begin{array}{l}\text { Ağır Solunum Yetmezliği } \\
\text { Hastalığı Sürveyansı (SARI- } \\
\text { Severe Acute Respiratory } \\
\text { Infection }\end{array}$ & Sözcü 10.03.2020 tarihli haberi \\
\hline Sürveyans & Sözcü 10.03.2020 tarihli haberi \\
\hline Adenorivüs & Posta 16.01.2020 tarihli haberi \\
\hline Entüba Hasta Sayısı & Milliyet 31.03.2020 tarihli haberi \\
\hline
\end{tabular}

Yukarıda başlıkları yer alan COVID-19 ile ilgili kısıtlı sayıdaki haberde dahi, aynı kavram için farklı belirtimlerin kullanıldığı görülmüştür. Öyle ki bazı haberlerde, aynı kavram için başlıkta farklı metin içinde farklı belirtimin kullanıldığı gözlemlenmiştir. Örneğin, Tablo 1'de görüldüğg̈ gibi, ilgili gazete haberlerinde, "COVID-19" teriminin 20 farklı yazılışına rastlanmıștır. Birbirinden farklı bu yazım şekilleri şöyledir: "Koronavirüs, Korona virüs, Korona, Korona virüsü, Corona Virüs, Corona virüs, Corona virüsü, Corona virisü (Koronavirüs), Korona virüs (COVID19), Koronavirüs (COVID-19), Koronavirüs (Covid-19), (Koronavirüs) Kovid-19, Koronavirüs (Kovid-19), Koronavirüs (kovid-19), Coronavirüs, Kovid-19, Covid19, COVID-19, Koronavirüs (Kovid-19), Corona Virüs (Kovid-19). Aynı terimin bu kadar çeşitli yazılış şekillerinin olması, yabancı kökenli terimlerin yanlış yazım biçimleriyle dile yerleşmesine sebep

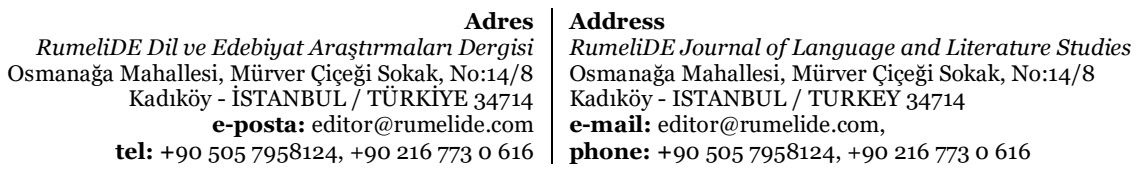


olabilmektedir. Bununla birlikte, çeşitli alanlarda terim kurullarının hazır bulundurulmasıyla, terimlerin doğru yazılışları en başından itibaren sağlanabilir ve terimlerin Türkçe karşılıklarının önerilmesiyle dilimizin zenginleștirilmesine zemin hazırlanabilir. İncelenen gazete haber örneklerinde, aynı terim için başlıkta farklı, metin içinde farklı yazılışın olması veya metin içinde farklı farklı yazılışların olması, genel olarak tutarsızlığa, dilin gelişememesine ve okurda kafa karışıklığına neden olmaktadır. Okur için basın organı olarak gazeteler önemli bilgi kaynaklarını temsil edebilmektedir. Halkı bilgilendirme amacı güden gazetelerin, dili doğru kullanmaları ve ayrıca standart terim kullanımına dikkat etmeleri, bilginin doğru anlaşılması ve dile uygun yapıların yerleşmesi için önemlidir.

COVID-19 terminolojisiyle ilgili Türkiye'deki bazı kurumsal düzenlemeler öncesinde, gazete haberlerinde yer alan COVID-19 terimleriyle ilgili diğer bir husus da terimlerin genel olarak yabancı kökenleriyle, diğer bir ifadeyle ödünçlenerek, kullanılmalarıdır. Tablo 1'de görüldüğü üzere, bazı haberlerde, çok az sayıda da olsa, terimlerin Türkçe karşıllklarının kullanıldığı görülmüştür. Örneğin, semptom yerine belirti, pnömoni yerine zatürre. Bununla birlikte, dilimize önceden yerleşmiş bu ve benzeri bazı terimlerin bazı haberlerde yabancı kökleriyle (semptom ve pnömoni olarak) kullanıldıkları gözlemlenmiştir (Bknz: Tablo 1). Dolayısıyla, incelenen gazete haber metinlerinde, sağlık terimlerinin ve daha özelde COVID -19 terimlerinin yabancı kökenli kullanımlarının yaygın olduğunu söylemek mümkündür.

Haberlerde geçen Tablo 1'deki COVID-19 terimleri, daha önce belirlediğimiz terim değerlendirme ölçütlerine göre değerlendirildiklerinde, yabancı kökenli terim kullanımının tercih edilmesiyle, terimlerin genel olarak "hedef gruba uygun olmadıkları"nı, diğer bir ifadeyle halka tam hitap etmediklerini, Türkçe karşılıkların kullanılmaması nedeniyle terimlerin anlaşılamaması, aynı kavram için çeşitli yazılışların olması ve yabancı köklerin Türkçe yazım kurallarına uygun kullanılmamaları nedeniyle "açılklı" ve "dilselmantıksal doğruluk" ölçütlerine uymadıklarını söylemek mümkündür. Ayrıca, yabancı köklerin türetilmesinde veya çekimlenmesinde birbirinden farklı oluşumların gelişmesi nedeniyle "türetilebilirlik / çekilebilirlik" ölçütünün sağlanamadığı durumların da ortaya çıtığı söylenebilir.

Bununla birlikte, COVID-19'un gelişimiyle ortaya çıkan yeni terimlere ilk etapta karşlık bulmak mümkün olmayabilir. Bu bağlamda, gazete haberlerinde yeni terimlerin yabancı kökleriyle kullanılması ilk etapta olağan görülebilir fakat gerekli terminolojik düzenlemeler yapıldıktan sonra basın organlarının resmi olan güvenilir kaynakları ivedilikle kullanması gerekir. Türkiye'de, terminolojik sorunların çözümünde etkili olabilecek COVID-19 ile ilgili bazı terminoloji çalışmaları yapılmıştır. Bu çerçevede, T.C. Sağlık Bakanlığı terimlerin tanım ve açılklamalarına yer verdiği “COVID-19 Sözlügü”nü yayımlamış ve Cumhurbaşkanlığı Kültür ve Sanat Politikaları Kurulu COVID-19 terimlerine Türkçe karşıllklar önermiştir. 0 halde, COVID-19 ile ilgili Türkiye'de gerçekleştirilen terminolojik düzenlemelerden sonra, gazete haberlerinde terimlerin kullanımıyla ilgili bir değişiklik olmuş mudur? Haberlerde terimlerin resmi kurumlarca önerilen tek tip standart yazılışına dikkat edilmiş midir? Terimler gazete haberlerinde Türkçe karş̧lıklarıyla mı yoksa yabancı kökleriyle mi yer almışlardır? Bir sonraki alt bölümde, Türkiye'deki COVID-19 terminolojisiyle ilgili düzenlemeler sonrasında yayımlanan bazı gazete haberleri incelenerek, terim kullanımlarında düzenlemelere paralel bir gelişim olup olmadığı açığa çıkarılacaktır.

Adres
RumeliDE Dil ve Edebiyat Araştırmaları Dergisi Osmanağa Mahallesi, Mürver Çiçeği Sokak, No:14/8 Kadıköy - ISTANBUL / TÜRKIYE 34714 e-posta: editor@rumelide.com tel: +90 $5057958124,+902167730616$
Address

RumeliDE Journal of Language and Literature Studies

Osmanağa Mahallesi, Mürver Çiçeği Sokak, No:14/8

Kadıköy - ISTANBUL / TURKEY 34714

e-mail: editor@rumelide.com,

phone: +90 $5057958124,+902167730616$ 
544 / RumeliDE Journal of Language and Literature Studies 2021.S9 (August)

COVID-19 Terms in Turkish print media: problems and solution suggestions / A. Turan; C. Yıldırım (pp. 525-551)

\subsection{Türkiye'deki COVID-19 terminolojisiyle ilgili düzenlemeler sonrasında COVID-19 terimlerinin gazete haberlerinde kullanımı}

Tablo 2: Türkiye'deki terminolojik düzenlemeler sonrasında bazı gazete haberlerinde geçen COVID-19 Terimleri

\begin{tabular}{|c|c|c|}
\hline $\begin{array}{l}\text { Gazete } \\
\text { haberlerinde } \\
\text { geçen COVID-19 } \\
\text { terimleri }\end{array}$ & \multicolumn{2}{|c|}{ Terimin geçtiği gazetenin adı ve haberin tarihi } \\
\hline Koronavirüs & \multicolumn{2}{|c|}{ Milliyet 15.06.2021 (5); Hürriyet 05.05.2021 (1); 19.06.2021(4) } \\
\hline Corona Virüs & \multicolumn{2}{|c|}{$\begin{array}{l}\text { Sabah } 31.05 .2020(5) ; 21.06 .2020(12) ; 31.07 .2020(9) ; 30.08 .2020(6) ; 30.10 .2020(7) ; \\
\text { 25.11.2020 (13); 21.12.2020(14); 27.01.2021(2); 25.02.2021 (2); 23.03.2021 (1); } 20.04 .2021 \\
\text { (1).Hürriyet 11.05.2020 (1); 28.02.2021 (1); 19.04.2021(2); 11.05.2021 (1); } 02.06 .2021 \text { (1) }\end{array}$} \\
\hline Entübe & \multicolumn{2}{|c|}{$\begin{array}{l}\text { Milliyet } 05.08 .2020 ; 03.09 .2020 ; 04.10 .2020 ; 11.11 .2020,04.12 .2020 ; 10.01 .2021 ; 05.02 .2021 ; \\
\text { 15.03.2021;12.04.2021;12.05.2021/ Hürriyet } 14.05 .2020 ; 26.06 .2020 ; 26.07 .2020 ; 06.08 .2020 \text {; } \\
\text { 13.09.2021; } 12.11 .2020 ; 2.12 .2020 ; 3.03 .2021 ; 01.05 .2021 / \text { Sabah }\end{array}$} \\
\hline Zirve /Pik & \multicolumn{2}{|c|}{ Sözcü 19.04.2020; Hürriyet 21.04.2020; Sabah 15.04.2020 } \\
\hline Bulaş riski & \multicolumn{2}{|c|}{ Hürriyet 16.04.2021; Sabah 11.05.2021; Sözcü 23.10.2020 } \\
\hline Otoimmün & \multicolumn{2}{|c|}{ Sabah 23.06.2021; Hürriyet 22.06.2021; Posta 03.06.2021 } \\
\hline Saha incelemesi & \multicolumn{2}{|c|}{ Hürriyet 02.05.2021; Sabah 27.05.2021; Sözcü 18.04.2020 } \\
\hline $\begin{array}{l}\text { Koronavirüs } \\
\text { Belirtileri }\end{array}$ & \multicolumn{2}{|c|}{ Sözcü 01.05.2021; Hürriyet 06.05.2021; Sabah 17.06.2021 } \\
\hline Damlacık & \multicolumn{2}{|c|}{ Sözcü 08.07.2020; Sabah 13.06.2021; Hürriyet 07.05.2021 } \\
\hline Tecrit & \multicolumn{2}{|c|}{ Sabah 21.06.2021; Sözcü 23.01.2021; Hürriyet 05.05.2021 } \\
\hline $\begin{array}{l}\text { Solunum cihazına } \\
\text { bağlı }\end{array}$ & \multicolumn{2}{|c|}{ Sözcü 02.11.2020; Sabah 23.06.2021; Hürriyet 21.05.2021 } \\
\hline Sürveyans & \multicolumn{2}{|c|}{ Hürriyet 21.05.2021; Sözcü 02.08.2020;Sabah 28.04.2021 } \\
\hline & $\begin{array}{r}\text { Adres } \\
\text { meliDE Dil ve Edebiyat Araştrrmaları Dergisi } \\
\text { nağa Mahallesi, Mürver Çiçeği Sokak, No:14/8 } \\
\text { Kadıköy - İSTANBUL / TÜRKIYE 34714 } \\
\text { e-posta: editor@rumelide.com } \\
\text { tel: +90 505 7958124, +90 216 773 0 616 }\end{array}$ & $\begin{array}{l}\text { Address } \\
\text { RumeliDE Journal of Language and Literature Studies } \\
\text { Osmanağa Mahallesi, Mürver Çiceği Sokak, No:14/8 } \\
\text { Kadıköy - ISTANBUL / TURKEY } 34714 \\
\text { e-mail: editor@ @rumelide.com, } \\
\text { phone: +90 505 7958124, +90 } 216773 \text { o } 616\end{array}$ \\
\hline
\end{tabular}


Tablo 2'den hareketle, COVID-19 terminolojisi ile ilgili Türkiye'deki düzenlemeler sonrasında, yabancı kökenli sözcüklerden ziyade Türkçede karşılığı önerilmiş terimlerin kullanılmaya başlandığını söylemek mümkündür. Öyle ki çalışmamızda düzenlemeler sonrası dönem olarak belirlenen Nisan 2020 sonrası gazete haberlerinde, yabancı terimler için önerilen Türkçe karşılıklara başvurulduğu gözlemlenmiştir. Gazete haber metinlerinde terimlerin Türkçe kullanımlarının yaygınlaşmasına ilişkin bu olumlu gelişme, terminoloji yönetiminin salgının başlangıcından itibaren gerçekleştirilmesinin önemini açıkça göstermektedir ve olası küresel salgınlar karşısında terim kurulunun gerekliliğini ortaya koymaktadır. Diğer bir husus ise, bazı yabancı kökenli terimlerin karşılığının olmaması veya uygun bir karşılık bulunamaması nedeniyle bu terimlerin düzenlemeler sonrası dönemde de, aynı morfolojik düzen ile yazılmaya devam etme eğilimi göstermesidir. Örneğin, kendi kendine gelen bağışıklık anlamında kullanılan oto immün terimi. Bununla birlikte, Türkiye'deki COVID-19 terminolojisiyle ilgili düzenlemeler sonrasında, Türkçe kullanımların basında artış göstermesi, devlet bünyesinde alınan terminolojik kararların ne kadar önem arz ettiğini ve dikkate alındığını göstermektedir. Bu nedenle, terimlerin en uygun kullanımları için terminoloji yönetiminin, küresel bir olayın yayılmasından önce başlatılması ve bunun için ilgili terim kurullarının hazır bulundurulması önemlidir.

Ayrıca, yabancı kökenli terimlere Türkçe karşılıklar önerilirken belirtim değerlendirme ölçütlerinin dikkate alınması önemlidir. Terminoloji çalışmasının amacına, hedef kitlesine ve işlevine göre bazı belirtim değerlendirme ölçütlerine uygunluk öncelikli olabilir. Çalışmamız kapsamında, gazete haberlerinde geçen COVID-19 terimleri incelendiğinden ve gazete haberlerinin temel olarak halkı bilgilendirme amaç ve işlevine sahip olmasından ötürü, terimlerin " hedef gruba uygunluk", "açıklık" ve "dilsel-mantıksal doğruluk" ölçütlerine uygunluğu öncelikli tutularak bu doğrultuda bir değerlendirme yapılmıştır. 27.06.2020 tarihli Milliyet haber metninde, İngilizce kökenli peak kelimesinin hedef kitleyle pik şeklinde aktarıldığı görülmektedir. Terimlerin ödünçlenerek kullanılması uluslararasılık ölçütüne uymakla birlikte, genelde ilgili alan uzmanlarına hitap etmektedir. Oysa hedef grubu daha geniş kitleler olan gazete gibi bir yayın organında terimlerin halkça anlaşılması önemlidir. "Gazi Üniversitesi Tıp Fakültesi Halk Sağlığı Öğretim Görevlisi ve Bilim Kurulu Üyesi Prof. Dr. Seçil Özkan, DHA'ya yaptığı açıklamasında, birinci dalganın pikinin yaşandığını, ikinci bir pik yaşanmaması için koruma önlemlerinin uygulanması gerektiğini kaydetti" söyleminde bulunurken sözcüğü yabancı kökeniyle kullanmıştır. Yabancı dil bilgisi olmayan halktan bireyler için bu durum bir güçlük teşkil etmektedir. Hürriyet gazetesi 23.10.2020 tarihli haberinde Sağllk Bakanı Fahrettin Koca "ilk zirveyi, bir diğer tabirle ilk piki büyük illerde 14 Nisan'da, ikinci zirve noktasını da eylülde yaşamıştık" şeklinde bir açıklamada bulunmuştur. Bu açıklama sayesinde pik kelimesinin Türkçe sözlük karşılığı olan zirve kullanılmıştır. Milliyet gazetesinin 8 Mayıs 2021 tarihli haber metninde ise "Hızla yayılan ve çocukları da etkileyen bu İngiltere mutasyonu ülkemizde 3. zirveyi görmemize sebep oldu" ifadesinde görüldüğü üzere, birebir zirve sözcüğü kullanılmıştır. Hürriyet gazetesi 19.05.2020 tarihli haber metninde, "Yeni tip koronavirüs salgınında her yaş grubunun hastalığa maruz kalabileceğini, ancak hastalı̆ı̆ı ağır enfeksiyona dönüşme ve hastaneye yatma ortalamasının yaş gruplarına göre farklılık gösterdiğini belirten Medicana Çamlıca Hastanesi Enfeksiyon Hastalıkları Uzmanı, Uzm. Dr. M. Kadir Göktürk" ün ifadesi "enfeksiyon" sözcüğünün yabancı kökenli kullanımını göstermektedir. Buna karşın, daha sonraki aylarda çıkan bir haberde, Milliyet gazetesi 05.11.2020 tarihli röportaj metninde geçen “...mevsim değişikliğiyle beraber soğuyan havayla birlikte rüzgârlı ve sisli havalarla daha sık karşılaşacağı ve bu durumun koronavirüsün bulaş riskini artırabileceği" ifadesi, yabancı terim (enfeksiyon) yerine "bulaş" Türkçe karşıllı̆ının tercih edildiğini göstermektedir. Morfolojik açından terimin kökeni yenidir, 
çünkü TDK'de bulaşıcı/bulaşıcılık sözcükleri yer almaktadır. İncelediğimiz gazete haber metinlerinden yola çıarak, COVID-19 terminolojisi ile ilgili düzenlemeler sonrasında, Türkiye'deki gazete haberlerinde COVID19 terimlerinin Türkçe karşllıklarının kullanımına daha fazla yer ve önem verildiğini söylemek mümkündür.

\section{Sonuç}

Bu çalışmada, Türkiye'de COVID-19 terminolojisinin hazırlanma ve kullanım evresi ile günlük kullanımda basın dilinden hareketle, terimlerin kullanımının değerlendirilmesi amaçlanmıştır. Haber metinlerinin bilgilendirici olması ve hedef kitleyi etkilemedeki önemli rolü açısından örneklemede Türkiye'deki yüksek tirajılı bazı ulusal gazetelerin COVID-19 ile ilgili haber metinlerine başvurulmuştur. Bu bağlamda, COVID-19 terimlerinin gazete haberlerindeki kullanımı Türkiye'deki COVID-19 ile ilgili terminolojik düzenlemeler öncesi dönem ile sonrası dönem olmak üzere iki dönemde incelenmiş ve belirtimlerin uygunlukları belirli belirtim değerlendirme ölçütleri çerçevesinde değerlendirilmiştir.

Türkiye'deki COVID-19 ile ilgili terminolojik düzenlemeler öncesi dönemde (hastalığın ilk üç ayında), gazete haberlerinde yabancı kökenli terim kullanımının yaygın olduğunu söylemek mümkündür. Ödünçlenen bazı yabancı terimlerin ise birbirinden farklı Türkçe yazılış şekilleri ile haber metinlerde yer aldığı görülmüștür. Örneğin, Tablo 1'de belirtilen, COVID-19 teriminin gazete haberlerindeki farklı Türkçe yazılışları. Bazı haber metinlerinde ise aynı terim için haber başlığında ayrı metin içinde ayrı yazılış şekillerinin kullanıldığı görülmüştür. Bu durum, özellikle COVID-19 teriminin haber başlığında ve metninde farklı yazılışlarıyla kendini göstermiştir. Gazete haberlerindeki COVID-19 terimlerinin ilgili belirtim değerlendirme ölçütleriyle uygunlukları değerlendirildiğinde, terimlerin genel olarak yabancı kökenleriyle ve farklı yazılış şekilleriyle kullanıldıklarını ve bu durumun 'hedef gruba uygunluk', 'açıklık', 'dilsel-mantıksal doğruluk' ve 'türetebilirlik/ çekilebilirlik' açılarından bazı sorunlar yarattığını söylemek mümkündür.

Türkiye'deki COVID-19 ile ilgili terminolojik düzenlemeler sonrası dönemde ise gazete haberlerinde terimlerin Türkçe karşılıklarının kullanımına doğru bir yönelim olduğu gözlemlenmiştir. Bu yönelimde T.C. Sağlık Bakanlığı ve Cumhurbaşkanlığı gibi resmi kurumların gerçekleştiği terminolojik girişim ve düzenlemelerin öneminin büyük olduğunu söylemek mümkündür. Öyle ki Cumhurbaşkanlığı Kültür ve Sanat Politikaları Kurulu tarafından yabancı terimlerin Türkçe karşılıklarının sunulduğu lügatçe güvenilir bir kaynak olması bakımından önemlidir ve yabancı kökenli terim kullanımıyla ilgili bazı sorunların çözümünde etkin bir yere sahip olduğu söylenebilir. Dolayısıyla, çeşitli alanlarda terim kurullarının hazır bulundurulması, salgın gibi acil eyleme geçilmesi gereken konularda terminoloji sorunlarının kısa sürede çözülmesine olanak sağlayacaktır. Böylece hem Türkçemiz gelişip zenginleşebilecek hem de salgın gibi acil eylem planı gerektiren konularda geç kalınmadan olumlu yönde bir gidişatın temelleri en baştan itibaren atılabilecektir.

\section{Kaynaklar}

Altun M. (2020). Salgin Günlerinde Sözcükler. https://www.facebook.com/groups/50794706990/posts/10156566941991991, Erişim Tarihi: 16.05.2021.

Altun M. (2020). Google Haber'den salgın sözcükleri. https://www.facebook.com/groups/50794706990/posts/10157463438721991, Erişim tarihi: 16.05.2021.

Aysan A. F., Balcı E., Karagöl E. T. ve diğerleri (2020). Covid-19 Pandemi Değerlendirme Raporu. Eds. Şeker M., Özer A., Tosun Z. ve diğerleri, Türkiye Bilimler Akademisi Yayınları, TÜBA Raporları No: 34, http://www.tuba.gov.tr/files/images/2020/kovidraporu/Covid-19\%20Raporu-Final+.pdf

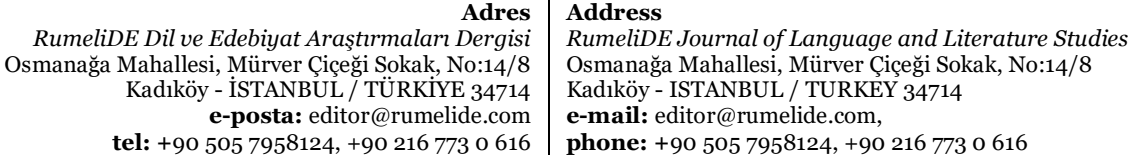


Çavdarcı G. (2020). Koronavirüs İle Hayatımıza Giren Terimler. https://www.hurriyet.com.tr/mahmure/yazarlar/gulcin-cavdarci/koronavirus-ile-hayatimizagiren-terimler-41495170, Erişim tarihi: 14.05.2021.

Çöl M. \& Güneş G., Evren E. \& Us E. ve diğerleri (2020). COVID-19. Eds. Osman Memikoğlu \& Volkan Genç, Ankara Üniversitesi Basımevi. http://www.medicine.ankara.edu.tr/wpcontent/uploads/sites/121/2020/05/COVID-19-Kitap.pdf, Erişim tarihi: 20.05.2021.

Drewer P., Pulitano D., Schmitz K. (2015). Terminoloji Çalışması - En İyi Uygulamalar 2.0. Türkçeye uyarlayan: Ender Ateşman, Grafiker Yayınları.

Eker S. (2020). Her Aynı Görünen Aynı Değildir II. https://www.facebook.com/SERA1962/posts/2515528488685921, Erişim tarihi: 16.05.2021.

Hasuder COVID-19 Görev Grubu (2020). Yeni Koronavirüs Hastalığı (COVID-19): Kavramlar ve Tanımlar Rehberi. https://korona. hasuder.org.tr/wp-content/uploads/Terminoloji28.3.2020.pdf, Erişim Tarihi: 15.05.2021.

Özdoğan M. (2020). Koronavirüs (COVID-19) SÖZLÜĞÜ: Bilinmesi gereken 20 terim. https://www.drozdogan.com/koronavirus-covid-19-sozlugu-bilinmesi-gereken-20terim/, Erişim tarihi: 14.05.2021.

Üren Ç. (2020). A'dan Z'ye Kovid-19: Koronavirüs terimleri sözlüğüu. https://www.indyturk.com/node/160731, Erişim tarihi: 14.05.2021.

Yılmaz Y. (2020). Cumhurbaşkanlığı Kültür Ve Sanat Politikaları Kurulu Türkçelerini Önerdi. https://www.facebook.com/groups/50794706990/posts/10156638737476991, Erișim tarihi: 16.05.2021.

Zülfikar H. (2011). Terim Sorunları ve Terim Yapma Yolları. Türk Dil Kurumu.

Zülfikar H. (2020). Gündemi Meşgul Eden Sağllk Terimleri, Türk Dili, 69 (821).

RumeliDE Dil ve Edebiyat Araştırmaları Dergisi Osmanağa Mahallesi, Mürver Çiçeği Sokak, No:14/8 Kadıköy - İSTANBUL / TÜRKIYE 34714 e-posta: editor@rumelide.com tel: +90 $5057958124,+902167730616$
Address

RumeliDE Journal of Language and Literature Studies Osmanağa Mahallesi, Mürver Çiçeği Sokak, No:14/8 Kadıköy - ISTANBUL / TURKEY 34714

e-mail: editor@rumelide.com

phone: +90 $5057958124,+902167730616$ 


\section{Online References}

https://covid19.saglik.gov.tr/TR-66394/covid-19-sozlugu.html, Erişim tarihi: 14.05.2021

https://journo.com.tr/tirajlar-2020, Erişim Tarihi: 19.05.2021.

https://www.milliyet.com.tr/milliyet-tv/bilim-kurulu-uyesi-uyardi-ikinci-bir-pik-yasayabiliriz-video6245554, Erişim tarihi: 21.05.2021.

https://www.sabah.com.tr/saglik/2021/05/08/mutasyonlu-viruste-kac-gun-olmali-uzmanindan-dikkatceken-izolasyon-aciklamasi, Erişim tarihi: 21.05.2021.

https://www.hurriyet.com.tr/kelebek/saglik/pandemi-surecinde-20-yas-alti-nelere-dikkat-etmeli41520788, Erişim tarihi: 23.05.2021.

https://www.hurriyet.com.tr/gundem/son-dakika-haberi-saglik-bakani-fahrettin-kocadan-onemliaciklamalar-41644457 Erişim tarihi: 21.05.2021

https://www.hurriyet.com.tr/dunya/cinde-sars-salgini-suphesi-41410963

https://www.hurriyet.com.tr/gundem/kocaeli-il-saglik-mudurlugunden-koronavirus-aciklamasi41434022,_Erişim tarihi: 23.05.2021.

https://www.hurriyet.com.tr/dunya/abd-koronavirus-tehdidi-nedeniyle-acil-durum-ilan-etti-41435313, Erişim tarihi: 23.05.2021.

https://www.hurriyet.com.tr/dunya/son-dakika-haberler-ve-korkulan-oldu-avrupada-korona-viruskaynakli-ilk-olum-41448079, Erişim tarihi: 23.05.2021.

https://www.hurriyet.com.tr/dunya/japonyadan-kovid-19-ile-mucadele-icin-2-5-milyar-dolarlik-paket41458300, Erişim tarihi: 23.05.2021.

https://www.hurriyet.com.tr/gundem/corona-virus-bilgilendirme-brosuru-81-ile-gonderildi-41459026, Erişim tarihi: 20.05.2021.

https://www.hurriyet.com.tr/aile/koronavirus-kaygisini-cocuklariniza-hissettirmeyin-41470043, Erişim tarihi: 20.05.2021.

https://www.hurriyet.com.tr/gundem/iyilesmis-hastanin-kaniyla-corona-virus-tedavisi-turkiyede-debasliyor-41482491, Erişim tarihi: 22.05.2021.

https://www.sabah.com.tr/saglik/2020/01/22/saglik-bakani-kocadan-son-dakika-grip-aciklamasi, Erişim tarihi: 22.05.2021.

https://www.sabah.com.tr/saglik/2020/01/31/corona-virus-belirtileri-nelerdir-corona-virusubelirtileri-nasil-fark-edilir, Erișim tarihi: 22.05.2021.

https://www.sabah.com.tr/saglik/2020/02/18/kovid-19-dunya-genelinde-73-binden-fazla-kisiyebulasti,Erişim tarihi: 21.05.2021.

https://www.sabah.com.tr/galeri/saglik/koronavirus-hakkinda-dogru-bilinen-yanlislar__Erișim tarihi: 22.05.2021.

https://www.sabah.com.tr/saglik/2020/03/02/saglik-bakanligi-bilim-kurulundan-koronavirus-brosuru ${ }_{2}$ Erişim tarihi: 20.05.2021.

https://www.sabah.com.tr/galeri/saglik/10-soruda-koronavirus-iste-koronavirus-ile-ilgili-bilmenizgerekenler, Erişim tarihi: 21.05.2021.

https://www.sabah.com.tr/saglik/2020/03/31/salgin-korkusu-varolan-psikiyatrik-hastaliklaritetikliyor ${ }_{\mathbf{L}}$ Erişim tarihi: 21.05.2021.

https://www.sozcu.com.tr/2020/saglik/enfeksiyon-hastaliklari-uzmani-dr-kadir-gokturk-anlattikoronavirusten-korunmanin-4-yolu-5600628/_Erişim tarihi: 22.05.2021.

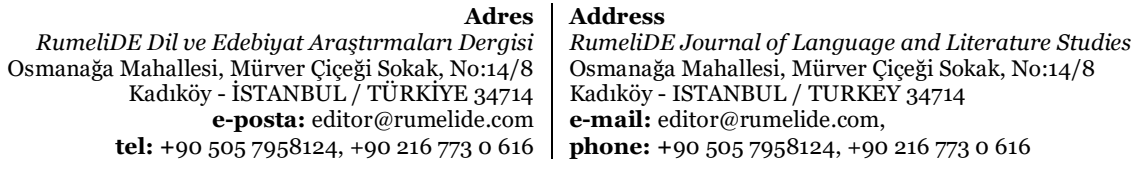


https://www.sozcu.com.tr/2020/gundem/istanbul-universitesinin-corona-virusu-raporu-ortaya-cikti5600119/, Erişim tarihi: 22.05.2021.

https://www.sozcu.com.tr/2020/dunya/corona-uyarisi-yapan-ve-susturulmak-istenen-doktora-da-virusbulasti-5606462/, Erişim tarihi: 21.05.2021.

https://www.sozcu.com.tr/2020/saglik/koronavirus-nesnelerin-uzerinde-ne-kadar-sure-yasayabilir5624953/, Erişim tarihi: 22.05.2021.

https://www.sozcu.com.tr/2020/saglik/prof-dr-colak-koronavirus-yayilma-hizi-azalacak-cunku5658383/, Erişim tarihi: 21.05.2021.

https://www.sozcu.com.tr/2020/saglik/yeni-koronavirus-enfeksiyonunu-teshis-edebiliyor-muyuz-olasibir-salgina-hazir-miyiz-5671370/, Erişim tarihi: 20.05.2021.

https://www.sozcu.com.tr/2020/gundem/corona-virusu-nedeniyle-karantinaya-alinan-il-ilce-mahalleve-koyler-5711405/, Erişim tarihi: 23.05.2021.

https://www.posta.com.tr/cinde-ortaya-cikan-virus-tum-dunyaya-yayilabilir-2234020, Erişim tarihi: 23.05.2021.

https://www.posta.com.tr/bakan-kocadan-coronavirus-aciklamasi-2236547, Erişim tarihi: 23.05.2021.

https://www.posta.com.tr/bakan-koca-ulkemizde-koronavirus-tanisi-alan-vatandasimiz-yok-2236855 Erişim tarihi: 22.05.2021.

https://www.posta.com.tr/dunya-saglik-orgutunden-hukumetlere-koronavirus-cagrisi-hazirlikli-olun2239350_Erişim tarihi: 20.05.2021.

https://www.posta.com.tr/metrobus-ve-duraklara-koronavirus-temziligi-2241583, Erişim tarihi: 23.05.2021.

https://www.posta.com.tr/turkiye-koronavirus-icin-etkin-onlemler-aldi-2243892, Erişim tarihi: 22.05.2021.

https://www.posta.com.tr/son-dakika-turkiyede-corona-virusten-olenlerin-sayisi-214e-yukseldi2246965_Erişim tarihi: 22.05.2021.

https://www.milliyet.com.tr/gundem/turkler-ambulans-ucakla-getirilecek-6132862, Erişim tarihi: 22.05.2021.

https://www.milliyet.com.tr/galeri/operasyon-tamam-ankaradaki-14-gunluk-karantina-basladi6134994/1, Erişim tarihi: 22.05.2021.

https://uzmanpara.milliyet.com.tr/haber-detay/gundem2/koronavirus-sonrasi-sirketler-tek-tekacikladi-onlarca-magaza-kapandi/98000/98736/, Erişim tarihi: 21.05.2021.

https://www.milliyet.com.tr/galeri/son-dakika-koronaviruste-sok-dalgalari-devlet-baskani-karantinada6154780/2, Erişim tarihi: 21.05.2021.

https://www.milliyet.com.tr/galeri/son-dakika-en-yetkili-isimden-soke-eden-koronavirus-aciklamasiiste-tehlikede-olan-4-ulke-6156820, Erişim tarihi: 20.05.2021.

https://www.milliyet.com.tr/gundem/corona-virusu-vaka-sayisi-ve-olum-sayisi-kac-oldu-turkiyedecorona-virusu-tablosu-6176415, Erişim tarihi: 21.05.2021.

https://www.milliyet.com.tr/gundem/pandemi-hastanesinin-yogun-bakim-unitesi-ilk-kez-goruntulendi6275266, Erişim tarihi: 5 Ağustos 2020

https://www.milliyet.com.tr/gundem/toplum-bilimleri-kurulu-uyesi-ilhan-aktif-vaka-sayisi-19-binlerecikti-6296830,Erişim tarihi 3 Eylül 2020

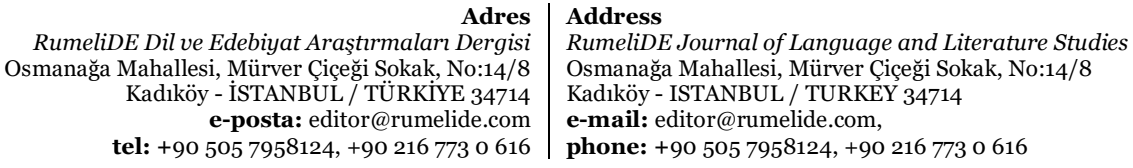


https://www.milliyet.com.tr/gundem/yogun-bakimdaki-baskan-bocekin-kritik-sureci-devam-ediyor6321630,Erişim tarihi 4 Ekim 2020

https://www.milliyet.com.tr/gundem/son-dakika-icislerinden-yeni-korona-genelgesi-81-ilde-yasaklandi6352520,Erişim tarihi 11 Kasım 2020

https://www.milliyet.com.tr/gundem/son-dakika-kadir-topbas-koronavirus-nedeniyle-yogun-bakimaalindi-6370999,Erişim tarihi 4 Aralık 2020

https://www.milliyet.com.tr/pembenar/corona-virusu-belirtileri-nelerdir-korona-virus-covid-19-tumbelirtileri-6402275 Erişim tarihi 10 Ocak 2021

https://www.milliyet.com.tr/dunya/almanyada-koronavirus-olumleri-60-bini-asti-6423856,

Erişim tarihi 5 Şubat 2021

https://www.milliyet.com.tr/ege/nefes-alacak-hal-birakmiyor-6456181, Erişim tarihi 15 Mart 2021

https://www.milliyet.com.tr/gundem/yogun-bakimlar-pek-cok-ilde-doldu-6479387,Erişim tarihi 12 Nisan 2021

https://www.milliyet.com.tr/gundem/onlar-bizim-meleklerimiz-karim-oldu-mu-6503768, Erişim tarihi 12 Mayıs 2021

https://www.hurriyet.com.tr/gundem/bilim-kurulu-uyesinden-dikkat-ceken-sozler-akil-alir-gibi-degil41517143, Erişim tarihi 14 Mayıs 2020

https://www.hurriyet.com.tr/gundem/prof-dr-mehmet-ceyhandan-10-hayati-oneri-41550648,Erişim tarihi 26 Haziran 2020

https://www.hurriyet.com.tr/gundem/turkiyenin-koronavirusle-mucadelesinde-son-24-saatteyasananlar-41573414,Erişim tarihi 26 Temmuz 2020

https://www.hurriyet.com.tr/yazarlar/osman-muftuoglu/pandemiye-fren-olabilecek-10-yeni-oneri41580467,Erișim tarihi 6 Ağustos 2020

https://www.hurriyet.com.tr/gundem/pandemi-doktoru-koronavirusle-mucadeleyi-anlatti-41610216, Erişim tarihi 3 Eylül 2020

https://www.hurriyet.com.tr/gundem/son-dakika-5-gun-arayla-iki-aci-olay-41660893, Erişim tarihi Kasim 2020

https://www.hurriyet.com.tr/dunya/entube-dogum-yapan-anne-hayatini-kaybetti-41677363, Erişim tarihi 2 Aralık 2020

https://www.hurriyet.com.tr/avrupa/yogun-bakimdakilerin-yarisi-gocmen-41753793,Erişim tarihi 3 Mart 2021

https://www.hurriyet.com.tr/gundem/ordudan-aci-haber-kari-koca-5-gun-arayla-koronavirusten-oldu41801291, Erişim tarihi Mayıs 2021

https://www.sabah.com.tr/galeri/yasam/son-dakika-haberi-bakan-koca-turkiyede-corona-virusugunluk-tabloyu-ve-son-durumu-paylasti-turkiyede-corona-virusu-vaka-olum-iyilesen-hasta-sayisikac-oldu/3,Erişim tarihi 29 Mayıs 2020

https://www.sabah.com.tr/kilis/2020/07/09/kiliste-korona-virusten-tedavi-goren-hasta-sayisi-65eyukseldi, Erişim tarihi 9 Temmuz 2020

https://www.hurriyet.com.tr/avrupa/futbola-yeniden-baslama-planlari-alt-ust-oldu-41514185, Erişim tarihi 10 Mayıs 2020

https://www.hurriyet.com.tr/galeri-son-dakika-haber-27-subat-koronavirus-tablosu-son-durum-turkiyecorona-virus-vaka-sayisinda-dikkat-ceken-yukselis-iste-covid-19-verilerinde-son-aciklamalar41746289, Erişim tarihi 28 Şubat 2021

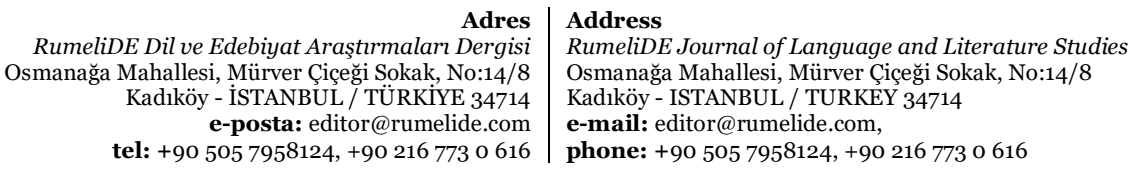


https://www.hurriyet.com.tr/galeri-corona-virus-gecirenler-ne-zaman-asi-olabilir-iste-covid-19-olanlaricin-ikinci-doz-asi-detayi-41823820, Erişim tarihi 02 Haziran 2021

https://www.hurriyet.com.tr/video/koronavirus-asilamasinda-yas-siniri-30a-indi-41835508, Erişim tarihi 19 Haziran 2021

https://www.sozcu.com.tr/2020/gundem/pik-yapmak-ne-demektir-pik-noktasi-nasil-oluyor5758466,Erişim tarihi 19 Nisan 2020

https://www.hurriyet.com.tr/gundem/pik-noktasi-3-mayista-41499346, Erişim tarihi

RumeliDE Dil ve Edebiyat Araştırmaları Dergisi Osmanağa Mahallesi, Mürver Çiçeği Sokak, No:14/8 Kadıköy - İSTANBUL / TÜRKIYE 34714 e-posta: editor@rumelide.com tel: +90 $5057958124,+902167730616$
Address

RumeliDE Journal of Language and Literature Studies Osmanağa Mahallesi, Mürver Çiçeği Sokak, No:14/8 Kadıköy - ISTANBUL / TURKEY 34714

e-mail: editor@rumelide.com,

phone: +90 $5057958124,+902167730616$ 